\title{
RAFAє SMOLEŃ
}

Uniwersytet Warszawski

\section{TRYB I GRANICE ZMIANY \\ KONSTYTUCJI GHANY Z 1992 R.}

\section{WPROWADZENIE}

Celem niniejszego opracowania jest przybliżenie problematyki formalnych i materialnych (postanowienia niezmienialne) ograniczeń zmiany Konstytucji Ghany z 1992 r., będących interesującym wyrazem transformacji tego państwa $z$ autorytaryzmu do demokracji. Ponieważ w zachodnich rankingach stanu demokracji, praworządności i przestrzegania praw człowieka Ghana od lat sytuuje się w ścisłej czołówce afrykańskiej - a w najnowszych osiąga wyniki bardzo zbliżone do Polski - warto tym bardziej przyjrzeć się jej bliżej.

Z chwilą powstania w 1957 r. Ghana - wcześniej brytyjska kolonia Złote Wybrzeże, część Brytyjskiej Afryki Zachodniej - była zaledwie trzecim niepodległym państwem w Afryce Subsaharyjskiej - poza Etiopią i Południową Afryką. Jako liderka afrykańskiej dekolonizacji i ruchu panafrykańskiego Ghana stała się dla wielu afrykańskich społeczeństw ważnym punktem odniesienia - jeśli nie symbolem - szybko podzieliła jednak los licznych innych formalnie niezależnych państw kontynentu, przez kilka dekad, z krótkimi przerwami, mierząc się z autorytarnymi rządami wojskowych.

Trwałą zmianę przyniósł przełom lat 80. i 90., kiedy to postępująca fala demokratyzacji w Afryce i innych miejscach świata, problemy gospodarcze i presja zachodnich państw i instytucji finansowych, w końcu także rosnący sprzeciw społeczny - zmusiły rządzącą od zamachu stanu 
z 31 grudnia 1981 r. Tymczasową Narodową Radę Obrony (Provisional National Defence Council) z płk. Jerrym Johnem Rawlingsem na czele do poważniejszych reform demokratycznych. To dodatkowo zaktywizowało i umocniło społeczeństwo obywatelskie, które, wcześniej rozproszone, zaczęło się organizować w ramach ruchów i partii politycznych i coraz ostrzej - i skuteczniej - występować przeciwko władzy².

W maju 1991 r. PNDC utworzyła dwustusześćdziesięcioosobowe Zgromadzenie Konsultacyjne, które miało przygotować projekt nowej konstytucji. W jego skład weszły 22 osoby powołane przez samą PNDC, 121 osób wskazanych przez 62 różnego rodzaju organizacje i 117 osób wybranych przez obsadzone w jedynie częściowo demokratycznych wyborach zgromadzenia dystryktów². Opracowując nową konstytucję, Zgromadzenie miało się kierować propozycjami - czy może raczej instrukcjami - PNDC, rekomendacjami powołanego przez nią komitetu konstytucjonalistów, a także konstytucjami z lat 1957, 1969 i 1979. Junta zapewniła sobie przy tym prawo do wprowadzania zmian do projektu konstytucji na dowolnym etapie prac. 31 marca 1992 r. Zgromadzenie przekazało projekt konstytucji PNDC, która zatwierdziła go jeszcze tego samego dnia. Ostateczny projekt konstytucji został ogłoszony zaledwie miesiąc przed referendum w jego sprawie, w dodatku w sytuacji, w której z uwagi na bardzo istotne ograniczenia działalności partii politycznych i wolności słowa w ogóle pluralistyczna debata konstytucyjna była

1 Por. K. BoAfo-Arthur, A decade of liberalism in perspective, [w:] Ghana: One Decade of the Liberal State, red. K. Boafo-Arthur, New York 2007, s. 9. O rządach Rawlingsa i ghańskiej transformacji ustrojowej zob. także np. E. AвAKA, Ghana: Revolution and Fourth Republic, 1981 to Present, [w:] Encyclopedia of African History, t. 1: A-G, red K. SHILlingTON, New York-London 2005; T.C. McCAskie, [Ghana] Recent History, [w:] Africa South of the Sahara 2004, red. K. Murison, London-New York 2004; K.G. Folson, Ideology, Revolution and Development - the Years of J.J. Rawlings, [w:] Ghana Under PNDC Rule, red. E. Gyimah-Boadi, Dakar 1993; K. Shillington, Ghana and the Rawlings Factor, London 1992; Z. Yeebo, Ghana: The Struggle for Popular Power, London 1991.

2 Ostatecznie Zgromadzenie obradowało w składzie dwieściepięćdziesięcioośmioosobowym, ponieważ Stowarzyszenie Adwokatów oraz Narodowy Związek Ghańskich Studentów odmówiły udziału w jego pracach, przekonując, że liczba zasiadających w nim przedstawicieli rządu jest zbyt duża. Zob. Ghana 1992, princeton.edu/ pcwcr/ reports/ghana1992.html (dostęp 15 marca 2017 r.). 
właściwie niemożliwa. W ogólnokrajowym referendum, które odbyło się 28 kwietnia 1992 r., przy frekwencji na poziomie 43,7\%, za przyjęciem nowej konstytucji opowiedziało się aż 92,6\%, a przeciw jedynie 7,5\% głosujących. 8 maja 1992 r. Rawlings, jako szef PNDC, podpisał konstytucję; weszła ona w życie 7 stycznia 1993 r.

Wybory prezydenckie, które odbyły się w listopadzie 1992 r., rozstrzygnęły się już w pierwszej turze - przy frekwencji na poziomie 50,2\% Rawlings zdobył 58,4\% głosów3 ${ }^{3}$. Obserwatorzy Wspólnoty Narodów uznali te wybory za zasadniczo wolne i uczciwe. Partie opozycyjne przekonywały jednak, że doszło w nich do licznych nieprawidłowości, a wręcz że zostały one sfałszowane. Przypominano, że jeszcze przed wyborami formułowano zarzuty dotyczące rzetelności spisów wyborców, jednak Tymczasowa Narodowa Komisja Wyborcza (INEC) odmówiła ich rozpatrzenia. Zwracano także uwagę na poważne ograniczenia w wolności działalności partii politycznych. Ostatecznie opozycja ogłosiła, że nie będzie podważać wyniku wyborów prezydenckich na drodze prawnej, zbojkotuje jednak nadchodzące wybory parlamentarne.

Z uwagi na zamieszki i liczne akty przemocy w kilku miastach kraju, będące wyrazem ogromnego napięcia politycznego, wybory parlamentarne przełożono o trzy tygodnie, na 29 grudnia 1992 r. Ponieważ, jak wspomniano, opozycja (NPP, PNC, NIP, PHP) zdecydowała się na ich bojkot, udział wzięły w nich jedynie Narodowy Kongres Demokratyczny (National Democratic Congress) - partia, w którą przekształciła się PNDC - oraz jej sojusznicy, NCP i EGLE Party. W takich warunkach NDC zdobył 77,5\% głosów, co dało mu 189 na 200 mandatów.

Stopniowy charakter i ograniczony zakres zmian demokratycznych, na jakie zgodziła się junta - wielokrotnie wycofując się zresztą ze swoich zapowiedzi w tym zakresie czy przekładając ich realizację - to, że wybory prezydenckie i parlamentarne były tylko częściowo wolne, w końcu także wewnętrzne podziały w łonie opozycji doprowadziły zatem do wygranej Rawlingsa i jego obozu politycznego. Można powiedzieć, że PNDC okazała się nie tylko najdłuższym rządem wojskowym w dziejach

3 Kandydaci opozycyjni, Albert Adu Boahen (NPP) i Hilla Limann (PNC), uzyskali odpowiednio 30,3\% i 6,7\% głosów. 
Ghany, lecz także jedynym, który przekształcił się w rząd cywilny ${ }^{4}$ Demokratyzacja systemu, choć w znacznej mierze wymuszona, pozwoliła na odnowienie legitymacji dla władzy Rawlingsa. Równocześnie jednak Konstytucja z 1992 r., choć przygotowana i uchwalona w tylko częściowo demokratycznej procedurze, a następnie zatwierdzona w tylko częściowo wolnym referendum, wyrażając najważniejsze zasady i wartości współczesnego konstytucjonalizmu, wprowadzała obowiązek sprawowania władzy w sposób demokratyczny, na podstawie i w granicach prawa, z poszanowaniem praw człowieka, a więc także możliwość demokratycznej kontroli i zmiany tej władzy.

Obecnie Ghana to państwo przeszło trzydziestodwumilionowe, bardzo zróżnicowane pod względem etnicznym i religijnym ${ }^{5}$. Jej system polityczny, oparty na zasadzie trójpodziału władzy, określić można, jeśli posługiwać się ukształtowanymi już terminami, mianem prezydenckiego. Konstytucja z 1992 r. ${ }^{6}$ powierza Prezydentowi, będącemu głową państwa i szefem rządu, szerokie kompetencje w wielu dziedzinach życia państwowego. Równocześnie przyznaje ona Parlamentowi (jednoizbowemu) istotne narzędzia ograniczania i hamowania jego władzy. Dotychczasowa praktyka polityczna pokazuje jednak, że parlamentarzyści niechętnie korzystają ze swoich kompetencji w tym zakresie. Twierdzi się wręcz, że Parlament ustąpił na rzecz Prezydenta „nie tylko w zakresie legislacji, ale w zasadzie w każdej dziedzinie polityki"7 i jako

\footnotetext{
4 K. Boafo-Arthur, op. cit.

5 47,5\% ludności Ghany stanowią Akanowie, 16,6\% Mole-Dagbon, 13,9\% Ewe, 7,4\% Ga-Dangme, 5,7\% Gurma, 3,7\% Guan, 5\% przedstawiciele innych mniejszości. $71,2 \%$ Ghańczyków jest chrześcijanami (zielonoświątkowcy i charyzmatycy - 28,3\%, protestanci - 18,4\%, katolicy - 13,1\%, inni - 11,4\%), 17,6\% muzułmanami, 5,2\% wyznaje tzw. religie tradycyjne, a 0,8\% inne religie; 5,2\% Ghańczyków deklaruje się jako bezwyznaniowi. Zob. The World Factbook - Ghana, cia.gov/the-world-factbook/countries/ghana/\#people-and-society (dostęp 4 sierpnia 2021 r.; dane w zakresie podziału etnicznego i religijnego na podstawie cenzusu ogólnokrajowego z 2010 r.).

6 Pod wieloma względami wyraźnie wzorowana na Konstytucji Stanów Zjednoczonych, a także brytyjskich rozwiązaniach konstytucyjnych.

S.K. Asare, H.K. Prempeh, Amending the Constitution of Ghana: Is the Imperial President Trespassing?, "African Journal of International and Comparative Law» 18.2/2010, s. 4.
} 
taki stanowi przedłużenie władzy wykonawczej ${ }^{8}$. Nieraz pisze się w tym kontekście o tradycji „monarszej prezydentury” (imperial presidency) lub „filozofii”, w myśl której zwycięzca bierze wszystko (winner takes all), właściwej także wielu innym państwom kontynentu' ${ }^{9}$.

W przypadku Ghany wpływ na taki stan rzeczy ma - między innymi - dość oryginalne rozwiązanie, wynikające częściowo z tekstu Konstytucji, a częściowo z tradycji i praktyki politycznej, w myśl którego począwszy od $1996 \mathrm{r}$. wybory prezydenckie (pierwsza tura) i parlamentarne odbywają się zawsze tego samego dnia (7 grudnia) - kadencje obu tych organów są czteroletnie - co raczej zmniejsza prawdopodobieństwo parlamentarno-prezydenckiej koabitacji.

We wspomnianych wyborach z 1996 r. ówczesne - post-PNDC-owe władze przedłużyły swój mandat. Z wynikiem na poziomie 57,4\% głosów Rawlings został wybrany na Prezydenta już w pierwszej turze, pokonując (przede wszystkim) Johna Kufuora z Narodowej Partii Patriotycznej (National Patriotic Party) (39,7\%). W wyborach parlamentarnych Rawlingsowski Narodowy Kongres Demokratyczny zdobył aż 133 na 200 mandatów (NPP - 61), o jeden mniej niż wynosi większość pozwalająca na zmianę Konstytucji.

Kolejne wybory z 2000 r. - w których z uwagi na konstytucyjne ograniczenie do dwóch kadencji Rawlings nie mógł już ubiegać się o prezydenturę - przyniosły jednak zmianę władzy. Wygrał je, w pierwszej turze, John Kufuor, główny rywal Rawlingsa sprzed czterech lat, pokonując Johna Attę Millsa z NDC. W wyborach parlamentarnych NPP Kufuora zdobyła równo 100 na 200 mandatów, o kilka więcej niż

8 Bertelsmann Stiftung, BTI 2020 Country Report - Ghana, Gütersloh 2020, bti-project.org/content/en/downloads/reports/country_report_2020_GHA.pdf(dostęp 1 czerwca 2020 r.), s. 9.

9 Por. np. H.K. Prempen, Presidential Power in Comparative Perspective: The Puzzling Persistence of Imperial Presidency in Post-Authoritarian Africa, "Hastings Constitutional Law Quarterly» 35.4/2008; R. GyAmpo, Dealing with Ghana's winner-takes-all politics: The case for an independent Parliament, "Governance Newsletter» 20.1/2015; IMANI Center for Policy \& Education, IMANI Policy Debate Series: Does Ghana Have A Winner-Takes-All Constitution?, imaniafrica.org/2014/09/14/ imani-policy-debate-series-does-ghana-have-a-winner-takes-all-constitution-2 (dostęp 14 września 2017 r.). 
NDC. Tym samym po 19 latach rządów Rawlingsa i po raz pierwszy w dziejach niepodległej Ghany nastąpiło pokojowe przekazanie władzy między przedstawicielami przeciwnych sobie obozów politycznych, wybranymi w wolnych wyborach. W literaturze wskazuje się nieraz na historyczny wymiar tego wydarzenia, dowodzącego trwałości ghańskiej transformacji ustrojowej, względnie będącego jej kamieniem milowym ${ }^{10}$.

W kolejnych latach obie główne partie polityczne - socjaldemokratyczny NDC i liberalno-konserwatywna NPP - wymieniały się władzą. W 2004 r. Kufuor w pierwszej turze po raz kolejny pokonał Attę Millsa, a jego partia (NPP) zdobyła 128 na 230 mandatów w Parlamencie (jego liczebność zwiększono) (NDC ,jedynie” 94 mandaty).

W wyborach z 2008 r. lepszy okazał się już jednak NDC, zdobywając dokładnie połowę mandatów w Parlamencie, o kilka więcej niż NPP (odwracając zatem sytuację sprzed ośmiu lat). W wyborach prezydenckich Atta Mills z NDC, otwarcie popierany przez Rawlingsa, przegrany sprzed czterech i ośmiu lat, tym razem wygrał, pokonując w drugiej turze kandydata NPP, Nanę Akufo-Addo, przewagą zaledwie 0,46\% głosów. Zacięta kampania wyborcza, niewielka różnica głosów między NPP a NDC i ich prezydenckimi kandydatami, a także to, że obie te partie zdobyły łącznie niemal 97\% wszystkich mandatów w Parlamencie, doprowadziły do pogłębienia polaryzacji sceny politycznej ${ }^{11}$.

Wybory z 2012 r. Nana Akufo-Addo z NPP również przegrał - wygrał je w pierwszej turze John Mahama z NDC, ówczesny Prezydent, zaprzysiężony na to stanowisko jako Wiceprezydent, po śmierci Prezydenta Atty Millsa pół roku wcześniej. W wyborach parlamentarnych NDC uzyskał 148 mandatów, zapewniając sobie bezpieczną większość głosów w dwustusiedemdziesięciopięcioosobowym Parlamencie (jego liczebność znów zwiększono), NPP zaś 123 mandaty.

Wybory z 2016 r. Akufo-Addo (wciąż NPP) już jednak wygrał, i to w pierwszej turze, pokonując Mahamę (wciąż NDC). NPP zdobyła także

10 Np. Institute of Economic Affairs, Democracy Consolidation Strategy Paper. An Issues Paper, Accra 2008, s. 15.

11 E. Gyimah-Boadi, V. Brobbey, Countries at the Crossroads 2012: Ghana, b.m.w. 2012, freedomhouse.org/sites/default/files/Ghana\%20-\%20FINAL.pdf (dostęp 1 czerwca 2020 r.), s. 1-2. 
zdecydowaną przewagę w Parlamencie - 169 na 275 mandatów; wszystkie pozostałe mandaty przypadły NDC - po raz pierwszy w IV Republice Parlament stał się więc wyłącznie dwupartyjny.

Akufo-Addo pokonał Mahamę także w 2020 r., również w pierwszej turze. W wyborach parlamentarnych doszło jednak do niezwykłej sytuacji - na 275 miejsc NPP i NDC uzyskały po 137; jeden mandat zdobył kandydat niezależny, w przeszłości członek NPP.

We wszystkich wyborach, począwszy od tych z 1996 r., frekwencja wynosiła między 60,4 a $85,1 \%$.

Widać więc, że z biegiem czasu w Ghanie ukształtował się system dwupartyjny, ani razu nie doszło do prezydencko-parlamentarnej koabitacji - choć w kilku przypadkach było do tego blisko - co w świetle wspomnianej wcześniej faktycznej pozycji politycznej kolejnych prezydentów i ogólnej bierności Parlamentu, niewykorzystującego możliwości, jakie daje mu Konstytucja, powoduje, że o ghańskiej polityce centralnej od lat decyduje kilka osób, wygrywających - prędzej czy później - wybory prezydenckie.

Mimo to zachodnie organizacje zajmujące się sprawami demokracji, praworządności i praw człowieka stwierdzają, stosunkowo zgodnie, że w tym zakresie sytuacja w Ghanie jest, na tle innych państw afrykańskich, bardzo dobra ${ }^{12}$. W najbardziej znanym tego rodzaju rankingu autorstwa Freedom House, w edycji opublikowanej w 2021 r., Ghana otrzymała 35 na 40 punktów w obszarze praw politycznych (Political Rights) i 47 na 60 punktów w obszarze swobód obywatelskich (Civil Liberties) ${ }^{13}$. Spośród krajów afrykańskich wyraźnie wyższe miejsce zajęły jedynie Republika Zielonego Przylądka (odpowiednio 38 i 54 punkty) i Mauritius (37 i 50), nieco wyższe Wyspy Świętego Tomasza i Książęca

\footnotetext{
12 Por. np. Bertelsmann Stiftung, op. cit., s. 3, 36.

13 Freedom House, Countries and Territories, freedomhouse.org/countries/ freedom-world/scores oraz Freedom in the World 2021: Ghana, freedomhouse.org/ country/ghana/freedom-world/2021 (dostęp 4 sierpnia 2021 r.). Po 2017 r. (wcześniej obowiązywała inna metodologia, w związku z czym wyniki byłyby trudne do porównania) liczba punktów dla Ghany niemal się nie zmieniała - zmiany oscylowały między 35 a 37 w przypadku praw politycznych oraz między 46 a 47 w przypadku swobód obywatelskich.
} 
(35 i 49), nieco niższe zaś Republika Południowej Afryki (33 i 46) ${ }^{14}$. Co należy podkreślić, Polska wypadła w tym rankingu właściwie tak samo jak Ghana (34 i 48$)^{15}$.

Przedmiotem szczególnej troski - od lat - są jednak prawa więźniów (więzienia są skrajnie przepełnione), dyskryminacja kobiet oraz mniejszości seksualnych, formalne obowiązywanie kary śmierci (wymierzanej przez sądy, jednak od 1993 r. niewykonywanej) ${ }^{16}$, a w ostatnim czasie także pogarszający się stan wolności mediów ${ }^{17}$. Ghański wymiar sprawiedliwości jest, ogólnie rzecz biorąc, uważany za faktycznie niezależny ${ }^{18}$.

\section{Tryb ZMiany Konstytucji}

a. Podstawowe zasady i warunki zmiany Konstytucji

Podstawowe zasady i warunki zmiany Konstytucji zostały określone w jej rozdziale XXV Zmiana Konstytucji (Amendment of the Constitution). Składa się on z czterech artykułów: art. 289 Zmiana Konstytucji, art. 290 Zmiana postanowień zasadniczych, art. 291 Zmiana postanowień zwykłych i art. 292 Akt zgodności z Konstytucją. Pierwszy z nich określa ogólne zasady i warunki zmiany wspólne dla wszystkich postanowień

14 Poza wymienionymi państwami afrykańskimi jeszcze tylko Namibię, Botswanę i Tunezję Freedom House klasyfikuje jako wolne (free); pozostałe uznaje za częściowo wolne (partly free) bądź pozbawione wolności (not free).

15 W 2017 r. liczba punktów dla Polski wynosiła odpowiednio 37 i 52.

16 Amnesty International, Ghana 2019, amnesty.org/en/countries/africa/ ghana/report-ghana (dostęp 1 czerwca 2020 r.). Por. np. United States Department of State - Bureau of Democracy, Human Rights and Labor, Country Reports on Human Rights Practices for 2016, Washington 2017; United States Agency for International Development, Ghana Democracy and Governance Assessment. Final Report, b.m.w. 2011, s. 10-11.

17 Por. Reporters Without Borders, 2020 World Press Freedom Index, rsf.org/ en/ranking (dostęp 1 czerwca 2020 r.).

18 Por. Bertelsmann Stiftung, op. cit., s. 10; European Commission, Action Document for the Ghana Anti-Corruption, Rule of Law and Accountability Programme (Ghana-ARAP) (ANNEX 1 of the Commission Decision on the Annual Action Programme 2015 in favour of the Republic of Ghana), b.m.w. 2015, s. 3. 
konstytucyjnych (zasadniczych i zwykłych). Jego ust. $1^{19}$ stanowi, że: „Zgodnie z postanowieniami Konstytucji Parlament może, w drodze ustawy, zmienić każde postanowienie Konstytucji "20, tym samym sugerując, że ustrojodawca zrezygnował z określenia, przynajmniej explicite, materialnych granic zmiany Konstytucji. Sprawa nie jest jednak oczywista, na co wskazuje już choćby rozpoczynające ten przepis zastrzeżenie: „Zgodnie z postanowieniami Konstytucji”; sformułowanie to, rozpoczynające również wiele innych postanowień Konstytucji, odgrywa ważną rolę w jej wykładni, będąc traktowane jako przypomnienie ogólnej zasady, w myśl której poszczególne przepisy Konstytucji należy czytać łącznie z innymi jej przepisami, zasadami i wartościami, a więc, mówiąc krótko, że Konstytucję należy czytać w całości ${ }^{21}$.

W niektórych konstytucjach, które - tak jak ghańska (postanowienia zasadnicze i zwykłe) - różnicują tryb swojej zmiany, zdarza się, że wybór tego właściwego stanowi przedmiot daleko idących wątpliwości i sporów.

19 Czyli art. 289 (1). Zgodnie z przyjętą w niniejszym tekście konwencją cyfra w nawiasie po numerze artykułu Konstytucji oznacza ustęp, a litera w nawiasie po numerze artykułu (ustępu) - literę.

20 Subject to the provisions of this Constitution, Parliament may, by an Act of Parliament, amend any provision of this Constitution. Wszystkie tłumaczenia fragmentów Konstytucji Ghany - z oryginalnej wersji w języku angielskim (języku urzędowym Ghany): The Constitution of the Republic of Ghana (Amendment) Act, 1996 (Act 527) są mojego autorstwa. W języku polskim nie istnieje choćby częściowe tłumaczenie tej Konstytucji.

${ }^{21}$ W ramach wyroku Sądu Najwyższego Ghany z 14 października 2015 r. w sprawie Asare vs Attorney General (J1/15/2015) - dostępnego na stronie Ghana Legal Information Institute: ghalii.org/node/245 - w swoim stanowisku na rzecz tego wyroku sędzia A.A. Benin stwierdza (s. 74), że rozpoczynające art. 289 (1) wyrażenie „Zgodnie z postanowieniami Konstytucji” należy rozumieć w ten sposób, że Parlament, wykonując swoją funkcję ustrojodawczą, powinien działać nie tylko na podstawie postanowień rozdziału XXV, lecz także w zgodzie z pozostałymi postanowieniami Konstytucji. Wyraz takiemu całościowemu podejściu do Konstytucji dają także w swoich zdaniach na rzecz tego wyroku sędzia G.T. Wood (s. 23-24), sędzia J.B. Akamba (s. 84, 93) i sędzia S.N. Gbadegbe, który obrazowo stwierdza (s. 64), że w przeciwnym wypadku „rozmaite części Konstytucji wydawałyby fałszywe dźwięki, niczym chór bez dyrygenta” („singing not in harmony but discordantly like a choir without a leader”). Por. także powołane w tym wyroku orzecznictwo. 
Problem nabiera dodatkowego wyrazu w odniesieniu do takich zmian konstytucji, których ciężar jest na tyle duży, że w ich wyniku mogłoby dojść do zmiany konstytucyjnej tożsamości państwa, uchwalenia „zupełnie nowej" konstytucji. Mając być może na względzie tego rodzaju problemy, ghański ustrojodawca uznał, że pojęcie zmiany konstytucji należy dość precyzyjnie zdefiniować (co jest praktyką w samych tekstach konstytucji stosunkowo rzadko spotykaną). I tak art. 295, opatrzony tytułem Interpretacja (Interpretation), zawarty w rozdziale XXVI Postanowienia różne, stanowi w ust. 9, że poprzez zmianę postanowień Konstytucji lub ustawy należy rozumieć także „zmianę, modyfikację, ponowne uchwalenie z poprawkami lub modyfikacjami, zawieszenie lub uchylenie postanowienia i ustanowienie w jego miejsce nowego postanowienia" 22 . Z podobnie dużą precyzją określono zresztą przesłanki, w jakich należy Konstytucji bronić ${ }^{23}$.

Twórcy Konstytucji, jak już wspomniano, podzielili jej postanowienia na dwie kategorie - postanowienia zasadnicze (entrenched provisions) i zwykłe (non-entrenched provisions) - z naturalną w takich przypadkach konsekwencją różnicując tryb ich zmiany. Katalog postanowień zasadniczych został określony w art. 290 (1) i ma charakter zamknięty; ponieważ Konstytucja nie wskazuje, które postanowienia należą do

22 "In this Constitution references to the alteration of any of the provisions of this Constitution or of an Act of Parliament include references to the amendment, modification, reenactment with amendment or modification, the suspension or repeal of that provision and the making of a different provision in place of that provision.”.

23 Zgodnie z art. 3 (3) Konstytucji: „Każdy, kto, samodzielnie lub z innymi osobami, przemocą lub przy pomocy innych bezprawnych środków, zawiesza, obala lub uchyla Konstytucję lub którąkolwiek jej część albo podejmuje takie próby lub też pomaga w takich działaniach lub do nich nakłania, dopuszcza się zdrady stanu i podlega karze śmierci.”. Zgodnie z kolejnym ustępem tego artykułu: „Wszyscy obywatele mają prawo i obowiązek nieustannie bronić Konstytucji, w szczególności stawiać opór działaniom, o których mowa w art. 3 (3), a w przypadku zawieszenia, obalenia lub uchylenia Konstytucji - czynić wszystko, co w ich mocy, aby ją przywrócić.”. Tak wyraźne wskazanie praw obywateli związanych z obroną ładu konstytucyjnego, a tym bardziej ich obowiązków w tym zakresie (obowiązku oporu), nie jest spotykane w konstytucjach innych państw świata. Por. np. znacznie ogólniejsze i warunkowe sformułowanie prawa do oporu wobec prób obalenia porządku konstytucyjnego (jeżeli inny sposób przeciwdziałania nie jest możliwy) w art. 20 ust. 4 Ustawy Zasadniczej Niemiec z 1949 r. 
zwykłych, należy przyjąć, że są to te, których nie uznano za zasadnicze. Decydując się na wyróżnienie tych, a nie innych postanowień jako zasadniczych, twórcy Konstytucji przyjęli przy tym podobne kryteria co ich odpowiednicy w wielu innych państwach demokratycznych za postanowienia zasadnicze uznano przede wszystkim te dotyczące podstawowych zasad ustroju państwa (głównie jednak prawnego i politycznego - te dotyczące ustroju społeczno-gospodarczego w większości uznano za zwykłe), a także te, które formułują prawa i wolności jednostki i wprowadzają gwarancje ich przestrzegania ${ }^{24}$.

Artykuł 289 (2) przewiduje, że zmiana Konstytucji wymaga łącznego spełnienia trzech następujących warunków: (1) jest ona dokonywana w drodze ustawy uchwalonej przez Parlament; (2) wyłącznym celem ustawy zmieniającej Konstytucję jest zmiana Konstytucji; (3) ustawa zmieniająca Konstytucję jest uchwalana zgodnie z postanowieniami rozdziału $\mathrm{XXV}^{25}$. W świetle tego i niżej omawianych przepisów należałoby uznać, że tak jak zmiana Konstytucji i zmiana ustawy zwykłej są dokonywane we właściwych im trybach, co zostało zresztą podkreślone w drugim ze wskazanych wyżej warunków (zakaz zblokowywania zmian konstytucyjnych i ustawowych), tak też powinno się dziać w przypadku zmiany postanowień odpowiednio zasadniczych i zwykłych Konstytucji - ustawa o zmianie postanowień zasadniczych nie powinna obejmować zmian w postanowieniach zwykłych i na odwrót. Zatem w przypadku chęci zmiany postanowień zarówno zasadniczych, jak i zwykłych wnioskodawcy powinni przygotować dwa odrębne projekty

24 Postanowienia zasadnicze są przy tym rozsiane po całym tekście Konstytucjiich katalog obejmuje przepisy umieszczone w 19 spośród 26 rozdziałów. Nie znalazły się w nim jedynie przepisy rozdziałów III Obywatelstwo, VI Zasady polityki państwa, IX Rada Stanu, XIV Służby publiczne, XVI Służba więzienna, XXII Ziemia i zasoby naturalne, XXIII Komisje dochodzeniowe, a także - o czym będzie jednak mowa później - postanowienia preambuły oraz obu załączników.

25 Dosłownie: „(2) This Constitutions hall not [pisownia oryginalna] be amended by an Act of Parliament or altered whether directly or indirectly unless - (a) the sole purpose of the Act is to amend this Constitution; and (b) the Act has been passed in accordance with this Chapter.”. Zwraca przy tym uwagę zastrzeżenie „ani bezpośrednio, ani pośrednio". 
- projekt ustawy o zmianie postanowień zasadniczych oraz projekt ustawy o zmianie postanowień zwykłych ${ }^{26}$.

\section{b. Inicjatywa w sprawie zmiany Konstytucji}

Konstytucja Ghany, mimo swojej znacznej objętości i szczegółowości, kilku istotnych zagadnień proceduralnych związanych ze swoją zmianą nie reguluje, czy też, podchodząc do tej sprawy z nieco innej strony, nie przewiduje odrębności w stosunku do postępowania w sprawie ustaw zwykłych. W szczególności nie określa ona - w sposób bezpośredni kręgu podmiotów dysponujących inicjatywą w sprawie swojej zmiany.

Wydaje się, że nic nie stoi na przeszkodzie, aby i w odniesieniu do Konstytucji Ghany przyjąć - praktykowaną w wielu innych systemach konstytucyjnych - zasadę odpowiedniego stosowania przepisów konstytucyjnych dotyczących zwykłego trybu ustawodawczego, tym bardziej że postępowanie w sprawie zmiany Konstytucji, zwłaszcza jej postanowień zwykłych, wykazuje do zwykłego trybu ustawodawczego wiele analogii $^{27}$. W konsekwencji należałoby uznać, że ponieważ zmiana Konstytucji dokonywana jest ustawą Parlamentu, to do postępowania w tej sprawie stosuje się, o ile przepisy Konstytucji, w tym zwłaszcza jej rozdziału XXV, nie stanowią inaczej, przepisy dotyczące postępowania w sprawie ustaw zwykłych. Wniosek ten byłby być może odmienny, gdyby odrębności postępowania w sprawie zmiany Konstytucji przewidywał Regulamin

26 Tak też w 2014 r. postąpił Prokurator Generalny - Minister Sprawiedliwości, składając w Parlamencie dwa odrębne projekty ustaw o zmianie Konstytucji: Constitution (amendment) (non-entrenched provisions) bill, 2014 oraz Constitution (amendment) (entrenched provisions) bill 2014. Stanowiły one rezultat prac prezydenckiego komitetu do spraw propozycji reform konstytucyjnych (Constitution Review Implementation Committee), o których mowa w dalszej części tekstu. Przewodniczący Parlamentu nadał tym projektom bieg, jednak z uwagi na zawieszenie procesu zmiany Konstytucji - o czym również dalej - ostatecznie nie zostały one uchwalone.

27 Informacje na temat przebiegu zwykłego postępowania legislacyjnego w Ghanie można znaleźć np. w: Friedrich Ebert-STiftung Ghana, The Law-making Process in Ghana: Structures and Procedures, Accra 2011, library.fes.de/pdf-files/bueros/ ghana/10506.pdf (dostęp 9 czerwca 2020 r.); bardziej skrótowe omówienie tego postępowania znajduje się na stronie Parlamentu Ghany: How laws are made, parliament. gh/laws (dostęp 9 czerwca 2020 r.). 
Parlamentu, ten jednak nie zawiera żadnych postanowień wyraźnie dotyczących zmiany Konstytucji ${ }^{28}$.

Konstytucja w art. 106 (14) - stanowiącym, że: „Projekt ustawy wniesiony do Parlamentu przez Prezydenta bądź w jego imieniu nie może być przedmiotem obrad komisji parlamentarnej dłużej niż przez trzy miesiące." ${ }^{29}$ - przyznaje Prezydentowi generalną inicjatywę ustawodawczą, a w art. 108 i art. 179 (1) przewiduje wyłączność prezydenckiej inicjatywy w sprawach odpowiednio ustaw finansowych i podatkowych (tzw. money bills) oraz ustawy budżetowej ${ }^{30}$.

Zarazem ze sposobu sformułowania art. 106 (14) - wskazującego na ograniczenie standardowej swobody komisji parlamentarnej w określaniu tempa swoich prac - oraz art. 108 i art. 179 (1) - formułujących przecież wyjątek od reguły - wynikałoby, że Konstytucja nie zawęża kręgu podmiotów zwykłej inicjatywy ustawodawczej tylko do Prezydenta, pozostawiając tę kwestię do regulacji w aktach niższej rangi. I tak Regulamin Parlamentu (art. 115, 122 i inne) uprawnienie to rozszerza na ministra i członka Parlamentu, działających samodzielnie bądź - co istotne - $\mathrm{w}$ imieniu Prezydenta.

Jak zauważa jednak sędzia P. Baffoe-Bonnie w przywoływanym już wyroku Sądu Najwyższego w sprawie Asare vs Attorney General (2015), „pod rządami Konstytucji z 1992 r. wszystkie [sic!] projekty ustaw, które następnie były uchwalane jako ustawy, [...] były wnoszone do Parlamentu przez Prokuratora Generalnego"31 (który zgodnie z art. 88 Konstytucji jest z urzędu ministrem). S.K. Asare i H.K. Prempeh, pisząc o politycznym zdominowaniu Parlamentu przez Prezydenta, podają wręcz, że po 1993 r. wszystkie projekty ustaw wnoszone do Parlamentu

28 Regulamin Parlamentu Ghany z 1 listopada 2004 r., yumpu.com/en/document/ read/11729002/standing-order-parliament-of-ghana (dostęp 9 czerwca 2020 r.). Jest to akt podkonstytucyjny, uchwalany przez Parlament na podstawie art. 110 Konstytucji.

29 „A bill introduced in Parliament by or on behalf of the President shall not be delayed for more than three months in any committee of Parliament.".

30 Można dodać, że zastrzeżenie dla władzy wykonawczej wyłączności inicjatywy ustawodawczej w niektórych sprawach z zakresu finansów publicznych jest często spotykane; nie szukając daleko, zob. np. art. 221 Konstytucji RP z 1997 r.

31 Sędzia P. Baffoe-Bonnie, op. cit., s. 59. 
(także te, które nie zostały później uchwalone) były tam wnoszone przez Prezydenta albo w jego imieniu (sic! ${ }^{32}$.

Dla omawianego problemu inicjatywy ustrojodawczej kluczowe znaczenie ma oczywiście art. 106 (14). W wyroku Sądu Najwyższego w sprawie Asare vs Attorney General (2015) uznano, że wyrażona w tym przepisie generalna inicjatywa ustawodawcza Prezydenta obejmuje również jego kompetencję do złożenia projektu ustawy o zmianie Konstytucji ${ }^{33}$. Wykładnia ta koresponduje zresztą z dotychczasową praktyką ustrojową: zarówno projekt ustawy o zmianie Konstytucji z 1996 r. która weszła w życie ${ }^{34}$ - jak i te projekty ustaw o zmianie Konstytucji, które ostatecznie nie zostały uchwalone - z lat 1999, 2014 (wspomniany kilka akapitów wcześniej) i 2016 - pochodziły właśnie od Prezydenta.

Skoro tak, to można postawić tezę, że przyznanie także innym niż Prezydent podmiotom - ministrowi, a przede wszystkim członkowi Parlamentu - prawa generalnej inicjatywy ustawodawczej (wobec niedopowiedzenia Konstytucji dokonane w sposób wyraźny w Regulaminie Parlamentu) oznacza wyposażenie tych innych podmiotów także w prawo inicjatywy ustrojodawczej. W podobny sposób wypowiadają się cytowani wyżej sędziowie Sądu Najwyższego, twierdząc,

32 S.K. Asare, H.K. Prempeh, op. cit., s. 4. Teza o desuetudo regulacji prawnych umożliwiających składanie projektów ustaw także innym podmiotom niż Prezydent lub Prokurator Generalny nie jest jednak w ghańskiej nauce i debacie publicznej formułowana, przynajmniej w ich głównym nurcie.

33 Tak - w swoich stanowiskach na rzecz tego wyroku - sędziowie J.B. Akamba, s. 45-46, S.N. Gbadegbe, s. 63-64, A.A. Benin, s. 77 czy G.T. Wood, s. 15. Ta ostatnia wskazuje, że gdyby twórcy Konstytucji chcieli ograniczyć rolę Prezydenta w inicjowaniu projektów ustaw o zmianie Konstytucji, to wprowadziliby wyraźne postanowienia w tym zakresie. Sędzia Gbadegbe odnajduje przy tym prezydenckie prawo inicjatywy ustrojodawczej również w art. 58 (2), stanowiącym, że zadaniem Prezydenta jest stosowanie Konstytucji i stanie na jej straży. Całkowicie odmiennie wypowiada się S.K. AsARE - inicjator wniosku do SN, który doprowadził do wydania przywoływanego wyroku - To Review or not to Review the CRC Judgment, graphic.com.gh/images/ pdfs/Asare_opinion.pdf (dostęp 3 lutego 2017 r.), s. 8, przekonując, że Prezydent nie jest uprawniony do wniesienia projektu ustawy o zmianie Konstytucji; jest natomiast zobowiązany do podpisania ustawy o zmianie Konstytucji.

34 Wprowadzone nią zmiany były niewielkie; najważniejszą z nich było osłabienie pozycji Wiceprezydenta na rzecz Prezydenta. 
że do wniesienia projektu ustawy o zmianie Konstytucji uprawnieni są zarówno Prezydent, jak i Parlament (jako taki, bez sprecyzowania w tym zakresie) $)^{35}$.

\section{c. Szczegółowe warunki zmiany Konstytucji}

Postępowanie w sprawie zmiany postanowień zwykłych Konstytucji zostało opisane w art. 291. W pierwszej kolejności projekt ustawy o zmianie tych postanowień jest dwukrotnie ogłaszany w dzienniku urzędowym, przy czym powtórna publikacja może nastąpić nie wcześniej niż trzy miesiące po pierwszej. Po upływie co najmniej $10 \mathrm{dni}$ od drugiej publikacji projekt trafia pod obrady Parlamentu, gdzie jest procedowany w trzech czytaniach. Po zakończeniu pierwszego czytania Przewodniczący Parlamentu (Speaker of Parliament) przekazuje go Radzie Stanu ${ }^{36}$ z prośbą o przedstawienie w ciągu 30 dni opinii. Projekt uznaje się za przyjęty, jeżeli w dwóch kolejnych głosowaniach, składających się odpowiednio na drugie i trzecie czytanie, opowie się za nim co najmniej dwie trzecie członków Parlamentu ${ }^{37}$. Nota bene zgodnie z art. 104 (4)

35 Tak w swoich stanowiskach na rzecz wyżej cytowanego wyroku sędziowie A.A. Benin, s. 77, J.B. Akamba, s. 75, S.N. Gbadegbe, s. 63-64 oraz - jak się wydaje G.T. Wood, s. 31 i n.

36 Rada Stanu pełni funkcje doradcze wobec Prezydenta i innych organów władzy (swoje niewiążące opinie może formułować w dowolnej sprawie - zob. art. 91 (3) Konstytucji). Formalnie, a w jeszcze większym stopniu w praktyce jest organem zależnym od Prezydenta.

37 Warto dodać, że nie jest to najwyższa znana Konstytucji większość. Zgodnie z art. 96 (2) (d) Parlament odwołuje swojego Przewodniczącego większością co najmniej trzech czwartych głosów swoich członków. Z tak wysokim wymogiem, niewątpliwie sprzyjającym niezależności Przewodniczącego, koresponduje art. 96 (1), zgodnie z którym Przewodniczący jest wybierany przez parlamentarzystów spośród parlamentarzystów oraz osób niebędących parlamentarzystami (sic!), ale mających bierne prawo wyborcze w wyborach parlamentarnych, przy czym parlamentarzysta wybrany na Przewodniczącego traci swój mandat parlamentarny. Nota bene o ile w przypadku brytyjskiej Izby Gmin, na której, jak się wydaje, wzorowane są ghańskie postanowienia konstytucyjne dotyczące organizacji Parlamentu, wymóg bezstronności Speakera przejawia się w „fakcie jego rezygnacji z przynależności partyjnej na początku urzędowania" (P. SARnecki, Wstęp, [w:] Podstawowe ustawy ustrojowe Zjednoczonego Królestwa Wielkiej Brytanii i Irlandii Północnej, Warszawa 2010, s. 13), o tyle w przypadku 
głosowanie w sprawie zmiany Konstytucji - podobnie jak głosowania personalne (nad wyborem lub odwołaniem danej osoby) - są tajne (in secret) ${ }^{38}$.

Postępowanie w sprawie zmiany postanowień zasadniczych Konstytucji zostało opisane w art. 290 (2)-(6). W pierwszej kolejności Przewodniczący Parlamentu kieruje projekt ustawy o zmianie tych postanowień do Rady Stanu z prośbą o przedstawienie w ciągu 30 dni opinii. Następnie projekt jest publikowany w dzienniku urzędowym. Dopiero po upływie sześciu miesięcy od tej publikacji Parlament może przystąpić do jego pierwszego czytania ${ }^{39}$.

Po zakończeniu pierwszego czytania, nieobejmującego wszakże parlamentarnego głosowania, projekt staje się przedmiotem głosowania w referendum ogólnokrajowym. Wynik referendum jest wiążący, jeżeli weźmie w nim udział co najmniej 40\% uprawnionych do głosowania, a co najmniej $75 \% \mathrm{z}$ nich opowie się za przyjęciem projektu ${ }^{40}$. Wynik

Parlamentu Ghany wprowadza się znacznie dalej idące gwarancje owej neutralności; może to wynikać ze słabszej niż w Zjednoczonym Królestwie tradycji parlamentarnej i kultury demokratycznej.

38 Jest to chyba jedna $\mathrm{z}$ bardziej oryginalnych cech ghańskiej Konstytucji. Z jednej strony można powiedzieć, że sprzyja to realizacji zasady suwerenności narodu, jako że uniezależnia głosowanie od dyscypliny partyjnej i innych bieżących, osobistych zobowiązań parlamentarzystów; z drugiej strony godzi w tę zasadę, choćby poprzez wyłączenie (ograniczenie) możliwości społecznej kontroli nad decyzjami parlamentarzystów w tej fundamentalnej przecież dla państwa sprawie.

39 Aż półroczny odstęp między tymi czynnościami należy do jednych z dłuższych znanych we współczesnych systemach demokratycznych.

40 Konstytucja przewiduje jeszcze dwa inne rodzaje referendum - referendum w sprawie zmiany granic regionów (najwyższy stopień podziału terytorialnego państwa) oraz referendum w pozostałych sprawach. Wynik tego pierwszego jest wiążący, jeżeli weźmie w nim udział co najmniej połowa uprawnionych do głosowania, a co najmniej $80 \%$ z nich opowie się za zmianą, przy czym w przypadku referendum w sprawie połączenia regionów wymaga się poparcia zmiany przez co najmniej $60 \%$ uprawnionych w każdym z tych regionów (frekwencja nie ma w tym przypadku znaczenia). Wynik referendum w pozostałych sprawach jest wiążący, jeżeli weźmie w nim udział co najmniej 35\% uprawnionych do głosowania, a co najmniej $70 \% \mathrm{z}$ nich opowie się za danym rozwiązaniem. Po 1992 r. odbyło się tylko jedno referendum - w 2018 r., w sprawie utworzenia sześciu nowych regionów. W zależności od regionu „za” zagłosowało wtedy od 99 do 99,7\% uprawnionych, a frekwencja wyniosła od 80 do $90 \%$ Zob. 
referendum jest wiążący dla Parlamentu w aspekcie negatywnym i pozytywnym: w przypadku nieosiągnięcia wymaganej większości lub „kworum” postępowanie ustrojodawcze ulega zakończeniu - Parlament jest zobowiązany do odrzucenia projektu, względnie do niepodejmowania żadnych dalszych kroków w tej sprawie; w przypadku osiągnięcia wymaganej większości i „kworum” Parlament jest zobowiązany do uchwalenia projektu przyjętego w referendum (bez możliwości wprowadzania do niego zmian).

Referendum stanowi zatem obligatoryjny i rozstrzygający element $\mathrm{w}$ postępowaniu w sprawie postanowień zasadniczych, wydaje się jednak wykluczone w postępowaniu w sprawie postanowień zwykłych ${ }^{41}$. I choć w obu tych postępowaniach to Parlament - a nie na przykład sami wyborcy w znanej niektórym państwom formule referendum ustawodawczego - ostatecznie uchwala ustawę o zmianie Konstytucji - potwierdzając tym samym przynależną mu, w zasadzie na wyłączność, funkcję prawodawczą - to w każdym z nich dysponuje on skrajnie odmiennymi kompetencjami. W postępowaniu w sprawie zmiany postanowień zwykłych Parlament odgrywa rolę kluczową, mogąc wprowadzać zmiany do projektu, a ostatecznie przyjąć go bądź odrzucić. W postępowaniu w sprawie postanowień zasadniczych rola Parlamentu ogranicza się do przeprowadzenia pierwszego czytania projektu, przy czym parlamentarzyści ani nad nim nie głosują, ani nie mogą wprowadzać doń żadnych poprawek.

A.R.A. SHABAN, Landslide approvals in Ghana referendum for new regions, 29 grudnia 2018 r., africanews.com/2018/12/29/landslide-approvals-in-ghana-referendum-for-new-regions (dostęp 4 sierpnia 2021 r.). Dodajmy przy tej okazji, że Ghana jest państwem unitarnym.

${ }^{41}$ Trudno byłoby przyjąć, że zmiana postanowień zwykłych Konstytucji może być przedmiotem referendum w pozostałych sprawach, w szczególności dlatego, że regulacje dotyczące tego rodzaju referendum zostały ujęte w rozdziale VII Przedstawicielstwo narodu, a nie w rozdziale XXV - należałoby założyć, że gdyby ustrojodawca przewidywał referendum w sprawie zmiany postanowień zwykłych, stosowne regulacje zawarłby w rozdziale XXV, tak jak uczynił to w przypadku zmiany postanowień zasadniczych. Por. sędzia G.T. Wood, op. cit., s. 15. 
d. Rola Prezydenta w postępowaniu w sprawie zmiany Konstytucji

Artykuł 290 (6) zobowiązuje Prezydenta do podpisania ustawy o zmianie postanowień zasadniczych Konstytucji uchwalonej przez Parlament w następstwie wiążącego go wyniku referendum, jednak pod warunkiem że została ona przyjęta zgodnie z procedurą określoną w Konstytucji. Podobnie art. 291 (3)-(4) przewiduje, że po przyjęciu ustawy o zmianie postanowień zwykłych Konstytucji Przewodniczący Parlamentu przedstawia ją Prezydentowi, który podpisuje ją pod warunkiem, że została ona przyjęta zgodnie z procedurą określoną w Konstytucji. Dodatkowo art. 292 (Akt zgodności z Konstytucją) stanowi, że Prezydent podpisuje ustawę o zmianie Konstytucji, która została przyjęta zgodnie z Konstytucją, pod warunkiem że Przewodniczący Parlamentu dołączył do niej dokument, który to stwierdza. W przypadku ustawy o zmianie postanowień zasadniczych dołącza się do niej także zaświadczenie Komisji Wyborczej stwierdzające, że zmiana ta została przyjęta $\mathrm{w}$ referendum zgodnie $\mathrm{z}$ postanowieniami rozdziału XXV.

Prezydent - inaczej niż w zwykłym postępowaniu ustawodawczym nie dysponuje zatem prawem weta wobec ustawy o zmianie Konstytucji ${ }^{42}$. Podkreśla się nieraz, że ponieważ Prezydent ma obowiązek podpisania ustawy o zmianie Konstytucji przyjętej zgodnie z trybem określonym w Konstytucji, jego rola w tym zakresie ma charakter jedynie „wykonawczy”43. Z treści przywołanych wyżej przepisów wynikałoby zarazem, że w sytuacji, w której ustawa o zmianie Konstytucji została przyjęta z naruszeniem procedury określonej w Konstytucji, Prezydent jest zobowiązany do odmowy jej podpisania. Wydaje się, że taki wniosek stanowi również konsekwencję zasady, zgodnie z którą organy władzy publicznej działają na podstawie i w granicach Konstytucji, wyrażonej

42 W przypadku zwykłego postępowania ustawodawczego Prezydent - na zasadzie wyjątku - nie dysponuje prawem weta wobec ustaw w sprawach finansowych (przypomnijmy jednak, że ma on wyłączność na ich wnoszenie), ale także ustaw, których projekty odpowiednia komisja parlamentarna uznała za pilne. To ostatnie uprawnienie Parlamentu (jego komisji) mogłoby istotnie ograniczać Prezydenta. Dopóki jednak większość parlamentarna traktować będzie Prezydenta jako swojego lidera, rozwiązanie to nie będzie przeciw niemu wykorzystywane.

43 Tak sędzia G.T. Wood, op. cit., s. 34. 
w jej preambule, a w odniesieniu do Prezydenta także w art. 58 (1), ponadto z treści art. 58 (2), zgodnie z którym Prezydent jest zobowiązany do stosowania Konstytucji i stania na jej straży.

\section{Granice ZMiany Konstytucji}

1. Obok formalnych ograniczeń zmiany konstytucji na stopień jej sztywności wpływ szczególny mają ograniczenia materialne (treściowe, merytoryczne). „Pytanie o granice zmiany konstytucji może się wydawać retoryczne" ${ }^{\prime 4}$. Z pozoru wydaje się przecież, że ustrojodawca, jeżeli tylko dochowa odpowiedniej procedury, może zmienić każde postanowienie swojej zasadniczej ustawy - w przeciwnym wypadku trudno byłoby twierdzić, że sprawuje on suwerenną władzę. Nadto obserwacja rzeczywistości wskazuje, że ustroje państwowe, aby przetrwać i zachować swoją społeczną użyteczność i atrakcyjność, muszą się nieustannie zmieniać, dostosowywać do zmiennych okoliczności zewnętrznych, a demokracja jako ustrój spośród wszystkich chyba najbardziej na ruch społeczny wrażliwy pozostaje w stałej transformacji instytucjonalnej ${ }^{45}$.

$\mathrm{Z}$ drugiej strony trudno nie zgodzić się z tezą, że taka zmiana konstytucji, która prowadziłaby do pozbawienia jej przymiotu demokratycznej - czyli gwarantującej ochronę praw i wolności jednostki, mniejszości i słabszych w konfrontacji z władzą silniejszej większości - choć w sensie faktów dokonanych (pozaprawnych) oczywiście możliwa, byłaby prawnie niedopuszczalna - zgodnie z założeniem, że prawa nie można stosować i interpretować w sposób, który prowadziłby do jego zniszczenia („samobójstwo konstytucyjne”). W tym kontekście przedstawiona wyżej teza o demokracji jako ustroju stałej transformacji instytucjonalnej nabiera właściwego jej znaczenia - konstytucja państwa demokratycznego podlega zmianie, ale tylko w granicach wyznaczonych przez swoją demokratyczną tożsamość. Otwarte pozostaje jednak

44 R. Piotrowski, Zagadnienie granic zmiany konstytucji w państwie demokratycznym, [w:] Ustroje, doktryny, instytucje polityczne. Ksiega jubileuszowa Prof. zw. dra hab. Mariana Grzybowskiego, red. J. CzAJKowski, Kraków 2007, s. 275.

45 Ibidem. 
pytanie o szczegółowy katalog elementów konstytutywnych ustroju demokratycznego, a w konsekwencji o dokładny zakres i granice zmiany demokratycznej konstytucji.

W niektórych państwach ustrojodawcy próbują odpowiedzieć na to pytanie, formułując w tekstach konstytucji tak zwane postanowienia niezmienialne ${ }^{46}$. Najczęściej postanowienia te obejmują podstawowe założenia ustroju politycznego oraz gwarancje praw i wolności jednostki, przybierając postać zakazów zmiany bądź nakazów ochrony określonych instytucji, rozwiązań lub zasad, zakazów naruszania bądź nakazów poszanowania określonych praw i wolności. Część z tych postanowień wyraża te wartości i zasady, które - jak się we współczesnym konstytucjonalizmie powszechnie uważa - wynikają z samej istoty systemu demokratycznego, takie jak nienaruszalność godności ludzkiej czy niezależność władzy sądowniczej, inne natomiast formułują zasady, czy nawet zakazy, których istnienie w państwie demokratycznym nie wydaje się wymagane, jak na przykład zasada federalizmu ${ }^{47} \mathrm{czy}$ zakaz nadawania tytułów szlacheckich ${ }^{48}$.

2. Postanowienia niezmienialne znajdziemy również w Konstytucji Ghany z 1992 r. Należą do nich art. 34, 35 i 37 Pierwszego Załącznika do Konstytucji zatytułowanego Postanowienia przejściowe ${ }^{49}$. Artykuły 34 i 35 określają zasady i warunki odpowiedzialności sądowej osób

46 Por. np. Y. Roznai, Unconstitutional Constitutional Amendments - The Migration and Success of a Constitutional Idea, «The American Journal of Comparative Law» 61.3/2013, który podaje (s. 667), że spośród 192 obecnie obowiązujących (2011 r.) konstytucji pisanych postanowienia niezmienialne zawierają 82 konstytucje, czyli $42 \%$.

47 Wyrażana np. w UZ Niemiec z 1949 r., w art. 79 ust. 3 i art. 20 ust. 1.

48 Wyrażany w art. 4 ust. 7 w związku z art. 110 ust. 1 Konstytucji Grecji z 1975 r.

49 Umieszczenie postanowień niezmienialnych w załączniku do Konstytucji można uznać za kolejną ghańską oryginalność. W dodatku postanowienia te zostały zawarte w końcowej części Pierwszego Załącznika zatytułowanej - jakby wbrew ich wadze - Postanowienia różne. W ghańskiej nauce i debacie publicznej przyjmuje się jednak, że załącznik ten stanowi integralną część Konstytucji. Kluczową rolę w tym zakresie, zwłaszcza w odniesieniu do wspomnianych art. 34, 35 i 37 tego załącznika, odgrywa art. 299 - ostatni przepis części „właściwej” (przed załącznikami) Konstytucji, o którym mowa w dalszej części niniejszego tekstu. 
sprawujących władzę w ramach kilku wcześniejszych reżimów wojskowych, a także zasady i warunki uzyskania zadośćuczynienia za działania i zaniechania takich osób. Zgodnie z art. 34 (1) ani członek PNDC, ani sekretarz PNDC, ani inne osoby mianowane przez PNDC nie mogą zostać obciążone odpowiedzialnością, ani zbiorową, ani indywidualną, za jakiekolwiek działanie lub zaniechanie z okresu rządów PNDC. Ustęp 2 tego artykułu przewiduje natomiast, że żaden sąd ani trybunał nie może prowadzić postępowania przeciwko rządowi Ghany ani jakiejkolwiek osobie działającej, zarówno przed, jak i po wejściu w życie Konstytucji, z upoważnienia rządu Ghany, ani też przeciwko osobie, która, działając wspólnie lub indywidualnie, doprowadziła do zmiany rządu lub wspierała działania mające na celu zmiany rządu, do których doszło 24 lutego 1966 r., 13 stycznia 1972 r., 4 czerwca 1979 r. i 31 grudnia 1981 r. - w sprawie działań lub zaniechań związanych z lub wynikających z: (a) obalenia rządów sprawujących władzę przed powstaniem NLC, NRC, SMC, AFRC ${ }^{50}$ i PNDC; (b) zawieszenia lub uchylenia Konstytucji z 1960, 1969 i 1979 r.; (c) utworzenia NLC, NRC, SMC rządzącej od 9 października 1975 r., SMC utworzonej 5 lipca 1978 r., AFRC i PNDC; a także (d) przyjęcia niniejszej Konstytucji (sic!). Ustęp ten nie pozwala także na przyznanie zadośćuczynienia za tego rodzaju działania lub zaniechania $^{51}$.

50 NLC - National Liberation Council - junta, która obaliła rządzącego od powstania państwa Kwame Nkrumaha, a w 1969 r. przekazała władzę w ręce wyłonionego w wyborach prodemokratycznego rządu cywilnego. Rząd ten został obalony w $1972 \mathrm{r}$. przez wojskowych, którzy utworzyli NRC - National Redemption Council, w 1975 r. odsuniętych jednak od władzy przez innych wojskowych, którzy następnie utworzyli SMC - Supreme Military Council. AFRC - Armed Forces Revolutionary Council - junta pod przywództwem Rawlingsa, która w czerwcu 1979 r. obaliła SMC, a w kolejnych miesiącach doprowadziła do przekazania władzy w ręce wyłonionego w wyborach prodemokratycznego rządu cywilnego. Rządy te zostały jednak obalone przez samego Rawlingsa w kolejnym puczu, w noc sylwestrową z 1981 na 1982 r., w wyniku którego powstała PNDC.

51 Warto odnotować, że w 2002 r. utworzono Narodową Komisję Pojednania, mającą działać na rzecz pojednania narodowego poprzez ustalenie prawdy o naruszeniach praw człowieka, przede wszystkim z czasów rządów wojskowych, ale także poprzez zadośćuczynienie tym, którzy zostali wówczas pokrzywdzeni. Por. Report of 
Kolejne postanowienia rozwijają i uszczegóławiają treść art. 34 (1)-(2). Ustęp 3 tego artykułu wyłącza możliwość prowadzenia postępowania, zresztą nie tylko sądowego, w sprawie działań wykonawczych, ustawodawczych lub sądowych podjętych przez PNDC, AFRC, członka PNDC lub AFRC lub osobę mianowaną przez PNDC lub AFRC, w tym możliwość przyznania zadośćuczynienia za takie działania. Artykuł 34 (5) przewiduje, że żaden sąd ani trybunał nie może prowadzić postępowania przeciwko osobie, która dopuściła się działania lub zaniechania niezgodnego z prawem obowiązującym przed lub w czasie rządów PNDC lub AFRC, jeżeli wynikało ono $z$ instrukcji lub z upoważnienia PNDC lub AFRC lub też członka PNDC lub AFRC. Artykuł 35 (1) przewiduje, że konfiskata własności i inne środki karne nałożone przez lub z upoważnienia AFRC lub PNDC, na podstawie dekretu lub ustawy wydanej przez AFRC lub PNDC, nie mogą zostać uchylone przez jakąkolwiek władzę na podstawie niniejszej Konstytucji. Artykuł 35 (2) zastrzega jednak, że w sytuacji, w której własność należąca do osoby fizycznej została skonfiskowana ze względu na sprawowanie przez nią urzędu publicznego lub politycznego bądź z jakiegokolwiek innego powodu, a Komisarz Praw Człowieka i Sprawiedliwości Administracyjnej ${ }^{52}$ uzna, że własność ta została nabyta przed objęciem przez tę osobę tego urzędu lub w inny sposób w zgodzie z prawem, powinna ona zostać tej osobie zwrócona.

W końcu, art. 37 przewiduje, że art. 34 i 35, podobnie jak sam art. 37, nie podlegają zmianie: „Nie uchybiając rozdziałowi XXV Konstytucji, Parlament nie jest uprawniony do zmiany niniejszego artykułu

the Constitution Review Commission, Accra 2011, constitutionnet.org/sites/default/ files/crc_research_report_final.pdf (dostęp 9 czerwca 2020 r.; dalej: Raport CRC), s. 794--795, 797-798, 800.

52 Komisarz przewodniczy trzyosobowej Komisji Praw Człowieka i Sprawiedliwości Administracyjnej (CHRAJ), która łączy w sobie tradycyjne zadania ombudsmana oraz agencji do spraw walki z korupcją. Tworzących Komisję Komisarza i dwóch jego zastępców powołuje, w porozumieniu z Radą Stanu, Prezydent. Komisja i Komisarz, z wyjątkiem przypadków określonych w Konstytucji, są niezależni w wykonywaniu swoich zadań; przesłanki i tryb, w jakich mogą zostać złożeni z urzędu, są analogiczne do tych, które dotyczą odpowiednio sędziego Sądu Apelacyjnego oraz sędziego Wysokiego Sądu. 
ani artykułów 34 i 35 niniejszego załącznika." ${ }^{3}$. Ponieważ organem, który zgodnie z rozdziałem XXV Konstytucji uchwala jej zmianę, jest Parlament, który dokonuje tego w ustawie (o zmianie Konstytucji) - od czego w żadnym innym przepisie Konstytucji nie czyni się wyjątku należy uznać, że ograniczenie kompetencji Parlamentu wprowadzone przez art. 37 Pierwszego Załącznika oznacza, że art. 34, 35 i 37 nie mogą zostać zmienione przez jakikolwiek inny organ.

Postanowienia legalizujące ex post naruszenia prawa stanowią w nad wyraz zmiennej ghańskiej historii ustrojowej już nieomal tradycję. W Konstytucji z 1969 r. była to sekcja 3 Pierwszego Załącznika, a w przypadku Konstytucji z 1979 r. sekcje 15 i 16 Pierwszego Załącznika. Te ostatnie przewidywały amnestię dla osób odpowiedzialnych za zamachy stanu z 4 czerwca 1979 r. (pierwszy pucz Rawlingsa), 13 stycznia 1972 r. (pucz Acheamponga) oraz 24 lutego 1966 r. (pucz Kotoki); dodatkowo podsekcje 2-4 sekcji 15 stanowiły, że żadne działanie ani zaniechanie wykonawcze, ustawodawcze ani sądowe podjęte przez AFRC lub w jej imieniu nie może być kwestionowane w jakimkolwiek postępowaniu, nawet jeżeli to działanie lub zaniechanie było niezgodne z prawem. O ile jednak wszystkie wymienione wyżej postanowienia II i III Konstytucji Republikańskiej należały do trudniejszych w zmianie postanowień zasadniczych (podział postanowień konstytucyjnych na zasadnicze i zwykłe również ma już swoją ugruntowaną tradycję), o tyle twórcy Konstytucji IV Republiki zdecydowali się przyznać postanowieniom amnestyjno-indemnizacyjnym walor niezmienności. Można to odczytywać jako dążenie do definitywnego zamknięcia rozrachunków z trudną historią i popełnianymi wówczas niegodziwościami, ale także jako warunek stosunkowo spokojnego przejścia z autorytarnych rządów wojskowych do demokracji konstytucyjnej. W tym kontekście warto też wspomnieć, że postanowienia te zostały wprowadzone do projektu Konstytucji przez samą juntę na ostatnim etapie prac w Zgromadzeniu Konsultacyjnym ${ }^{54}$.

53 „Notwithstanding anything in Chapter 25 of this Constitution, Parliament shall have no power to amend this section or sections 34 and 35 of this Schedule.".

54 Por. Raport CRC, s. 798-799. 
Warto raz jeszcze podkreślić, że twórcy ghańskiej Konstytucji uznali za niezmienialne nie tylko art. 34 i 35 Pierwszego Załącznika, lecz także samo postanowienie, w którym tę ich niezmienialność wyrazili. Formułowanie odrębnych postanowień stanowiących o niezmienialności innych postanowień jest praktyką często, choć nie powszechnie spotykaną ${ }^{55}$. Do rzadkości należą jednak konstytucje, które - tak jak ghańska - wprost formułują zasadę niezmienialności samej klauzuli niezmienialności określonych postanowień. Brak zachowania takiej, można by powiedzieć, precyzji nie musi wprawdzie stać na przeszkodzie uznaniu, że postanowienie stanowiące o niezmienności innego postanowienia jest samo w sobie niezmienialne ${ }^{56}$, podejście do niezmienności klauzuli niezmienialności jest jednak zróżnicowane ${ }^{57}$.

Warto przy tym zwrócić uwagę na treść art. 299 - ostatniego przepisu części „właściwej” ghańskiej Konstytucji - który stanowi, że postanowienia przejściowe określone w Pierwszym Załączniku wywierają skutek niezależnie od czegokolwiek innego w Konstytucji, co stałoby z nimi w sprzeczności. Oznacza to, że w przypadku, w którym postanowienia przejściowe weszłyby w konflikt $\mathrm{z}$ innymi postanowieniami Konstytucji, w toku wykładni należy przyznać tym postanowieniom przejściowym pierwszeństwo $^{58}$. W odniesieniu do art. 34, 35 i 37 Pierwszego Załącznika dyrektywa ta stanowi, jak się wydaje, dodatkowe potwierdzenie ich szczególnej mocy prawnej. W ghańskiej debacie prawniczej pojawiają się jednak głosy - o czym mowa niżej - że może być ona traktowana

55 Por. np. przywoływany już art. 79 ust. 3 UZ Niemiec z 1949 r., przesądzający o niezmienności zarówno tych zasad, które zostały w nim wyrażone w sposób bezpośredni, jak i tych zawartych w postanowieniach, do których artykuł ten odsyła (art. 1 i 20).

56 W niektórych systemach konstytucyjnych przyjmuje się, że niezmienialność klauzuli niezmienialności jest logiczną konsekwencją istnienia tej klauzuli, nawet jeżeli nie zostało to wyrażone w tekście konstytucji w sposób bezpośredni. Tak na przykład uznał w 1991 r. niemiecki Federalny Trybunał Konstytucyjny w odniesieniu do UZ Niemiec z 1949 r. Por. L. Garlicki, Normy konstytucyjne relatywnie niezmienialne, [w:] Charakter i struktura norm konstytucji, red. J. TRzCIŃski, Warszawa 1997, s. 145-146.

57 R. Piotrowski, op. cit., s. 281-282.

58 Por. Raport CRC, s. 793. 
w sposób zupełnie przeciwny - jako podstawa relatywizacji niezmienności tych trzech artykułów.

3. Artykuły 34, 35 i 37 Postanowień przejściowych to jedyne przepisy Konstytucji, które zostały - w samym jej tekście - w sposób wyraźny uznane za niepodlegające zmianie. Teksty niektórych konstytucji wyrażają wszakże granice swojej zmiany w sposób mniej konkretny, odwołując się do pewnego zestawu wartości czy wręcz „ducha” prawa ${ }^{59}$. $\mathrm{W}$ przypadku niektórych konstytucji granice ich zmiany są zaś z ich tekstu niejako wydobywane - jako implikowane zakazy zmiany - w drodze wykładni, przede wszystkim poprzez orzecznictwo sądowokonstytucyjne oraz - ze skutkiem już formalnie niewiążącym, choć w praktyce nieraz nie mniej znaczącym - doktrynę prawa.

W określaniu granic zmiany konstytucji ważną rolę odgrywa niekiedy jej wstęp. Preambuła Konstytucji Ghany rozpoczyna się od słów: „Wykonując nasze naturalne i niezbywalne prawo do ustanowienia systemu rządów, które zabezpieczą dla nas i dla potomności dobrodziejstwa wolności, równość szans i dostatek" ${ }^{\circ}$. Z tego pierwszego - po invocatio Dei - wiersza Konstytucji, wskazującego na jej cel gwarancyjny, wynika, że za naczelne wartości ustrojodawca uznał triadę: wolność - równość (szans) - dobrobyt. W dalszej części preambuły w sposób uroczysty deklaruje i potwierdza się przywiązanie do wolności, sprawiedliwości, uczciwości i odpowiedzialności, „zasady, zgodnie z którą wszelka władza pochodzi z suwerennej woli Narodu”, „zasady powszechnego prawa wyborczego osób dorosłych” oraz rządów prawa, zobowiązuje się także do „ochrony podstawowych praw i wolności człowieka, jedności i stabilności naszego państwa"61. Wydaje się, że wolność ma dla

59 O „duchu Konstytucji”, ograniczającym jej zmiany, mówi art. 112 ust. 1 Konstytucji Norwegii z $1814 \mathrm{r}$.

${ }^{60}$ „IN EXERCISE of our natural and inalienable right to establish a framework of government which shall secure for ourselves and posterity the blessings of liberty, equality of opportunity and prosperity.”.

${ }^{61}$ Wiele z wyrażonych w preambule zasad zostało powtórzonych w art. 35 (Cele polityczne), zawartym w rozdziale VI Zasady polityki państwa, w myśl którego (ust. 1): „Ghana jest państwem demokratycznym urzeczywistniającym zasady wolności i sprawiedliwości; zgodnie z powyższym władza suwerenna należy do narodu Ghany, od którego rząd, poprzez Konstytucję, wywodzi wszystkie swoje kompetencje.”. W ust. 6 
ustrojodawcy znaczenie szczególne, skoro pojawia się w preambule aż dwukrotnie ${ }^{62}$. Podkreślić przy tym należy, że ghańskie orzecznictwo konstytucyjne przypisuje postanowieniom preambuły Konstytucji wartość normatywną ${ }^{63}$.

W przywołanym pierwszym zdaniu preambuły prawo do ustanowienia określonego systemu rządów, to znaczy takiego, który „zabezpieczy dla nas i dla potomności dobrodziejstwa wolności, równość szans i dostatek", zostało wywiedzione z prawa naturalnego i uznane za niezbywalne. W konsekwencji można by stwierdzić, że obywatele Ghany, jako twórcy i adresaci swojej Konstytucji, dobrowolnie zrezygnowali z prawa do takiego ukształtowania ustroju państwa, które by ich pozbawiało - zarówno obecne, jak i przyszłe pokolenia - możliwości ustanowienia władzy stojącej na straży wolności, równości szans i dobrobytu. Oznaczałoby to, że każda zmiana Konstytucji, będąca przecież aktem stosowania odpowiednich postanowień Konstytucji, w szczególności zawartych w rozdziale XXV przepisów określających procedurę jej

lit. d tego artykułu znajdziemy również, ważne z punktu widzenia zasad zmiany Konstytucji, zobowiązanie władz państwowych do zapewnienia obywatelom możliwości udziału w procesie podejmowania decyzji na każdym poziomie życia państwowego.

62 Wolność i sprawiedliwość to zresztą słowa widniejące w herbie Ghany, ustanowionym wszakże jeszcze przez Elżbietę II, na dwa dni przed powstaniem państwa. Wolność osobista, a zwłaszcza zasady i warunki jej pozbawienia, znalazła przy tym szeroką i szczegółową regulację konstytucyjną (por. zwłaszcza art. 32). Z pewnością duży wpływ miały na to - znów - trudne doświadczenia historyczne, zwłaszcza pamięć o ustawie o areszcie prewencyjnym z 1958 r., która upoważniała rząd do przetrzymywania w więzieniu - przez okres do pięciu lat, z możliwością przedłużenia - osób jedynie podejrzanych o udział $\mathrm{w}$ działaniach przeciwko bezpieczeństwu państwa. Dodatkowo, na mocy wprowadzonych w kolejnym roku zmian w Konstytucji z 1957 r., osoba poddana aresztowi prewencyjnemu traciła bierne prawo wyborcze w wyborach do Zgromadzenia Narodowego, a jeżeli była już jego członkiem - mandat członka Zgromadzenia. Na tej podstawie Nkrumah uwięził lub zmusił do emigracji setki opozycjonistów, w tym wielu parlamentarzystów, co w krótkim czasie sprawiło, że parlament pierwszej kadencji stał się de facto jednopartyjny.

${ }_{63}$ Tak np. w zdaniach poszczególnych sędziów na rzecz wyroku SN w sprawie Asare vs Attorney General (2015), s. 41, 51, 131-133, 157. 
zmiany $^{64}$, powinna służyć, zgodnie z treścią preambuły, kształtowaniu takiego systemu rządów, który zapewni obecnym i przyszłym pokoleniom „wolność, równość szans i dostatek”.

Wśród postanowień Konstytucji, które wyrażają granice jej zmiany i jako takie nadają rozdziałowi XXV znaczenie merytoryczne, można wskazać również w szczególności art. 15 (2), który stanowi, że godność ludzka jest nienaruszalna ${ }^{65}$. Warto także zwrócić uwagę na zawarty w rozdziale V Podstawowe prawa $i$ wolności art. 33 (Sądowa ochrona praw) (5), który stanowi, że wskazane w tym rozdziale prawa, obowiązki, zapewnienia (zobowiązania) i gwarancje dotyczące podstawowych praw i wolności człowieka nie wyłączają innych, niewyrażonych w tym rozdziale w sposób bezpośredni, praw i wolności „uznanych za nieodłączne dla demokracji i mających na celu zabezpieczenie wolności i godności człowieka". Tym samym przepis ten, odwołując się do prawa ponadpozytywnego i aksjologii systemu demokratycznego, dokonuje otwarcia konstytucyjnego katalogu praw i wolności, w duchu tezy zakładającej, że człowiekowi przysługują nie tylko te prawa i wolności, które zapisano w konstytucji - prawa i wolności zapisano w konstytucji, dlatego że one nam przysługują ${ }^{66}$.

64 Por. R. Piotrowski, Konstytucja i granice władzy suwerena w państwie demokratycznym, [w:] Dwadzieścia lat obowiązywania Konstytucji RP. Polska myśl konstytucyjna a międzynarodowe standardy demokratyczne, red. J. Jaskiernia, K. SPRYszak, Kielce 2017, s. 722-723.

65 „The dignity of all persons shall be inviolable.”. W ust. 2 mowa jest, że „Nikt, także osoba pozbawiona wolności, nie może być poddany torturom ani innemu okrutnemu, nieludzkiemu lub poniżającemu traktowaniu lub karaniu ani nie może przebywać w warunkach, które pozbawiają go lub z dużym stopniem prawdopodobieństwa mogą go pozbawić godności i wartości jako osoby ludzkiej.”. Por. art. 35 (2)-(4).

${ }_{66}$ Tak R. Piotrowski, wypowiedź na wspólnym posiedzeniu Komisji Praw Człowieka, Praworządności i Petycji, Komisji Ustawodawczej oraz Komisji Samorządu Terytorialnego i Administracji Państwowej Senatu RP 4 maja 2020 r. poświęconym rozpatrzeniu ustawy z 6 kwietnia 2020 r. o szczególnych zasadach przeprowadzania wyborów powszechnych na Prezydenta Rzeczypospolitej Polskiej zarządzonych w 2020 r., stenogram dostępny na stronie senat.gov.pl/prace/komisje-senackie/przebieg,8625,2. html. 
O ile zatem rozdział XXV określa „jedynie” procedurę zmiany Konstytucji, o tyle preambuła, art. 15 (2), art. 33 (5) oraz art. 34, 35 i 37 Postanowień przejściowych wyznaczają materialne granice tej zmiany.

Zawarty już w rozdziale VI Podstawowe zasady polityki państwa art. 41 (Obowiązki obywatela) stanowi przy tym nieco mgliście, że korzystanie z praw i wolności jest nieodłącznie związane z wywiązywaniem się z obowiązków obywatelskich (które następnie zostają tam wymienione ${ }^{67}$ ).

\section{Zasady Zmiany Konstytucji a Debata nad Jej ZMianĄ Z LAT 2010-2016}

Tak jak w życiu człowieka osiągnięciu pełnoletności często towarzyszą nowe plany, wyzwania i nadzieje, ale i nuta niepewności, tak też osiemnasta rocznica uchwalenia i wejścia w życie ghańskiej Konstytucji przypadła na początek wzmożonych prac nad jej ewentualną zmianą, dyskutowanych wszakże od dłuższego czasu. W 2010 r. Prezydent John Atta Mills, przy aprobacie wszystkich głównych sił politycznych i znacznej części opinii publicznej, utworzył komisję do spraw oceny i zmiany Konstytucji (Constitution Review Commission) ${ }^{68}$. Po niemal dwóch latach prac, w grudniu 2011 r., CRC złożyła na ręce Prezydenta raport

${ }^{67}$ Wśród nich znajduje się obowiązek „podtrzymywania i obrony Konstytucji i prawa" (art. 41(b)).

68 Por. M. van Vliet, W. Wahiu, A. Magolowondo, Constitutional Reform Processes and Political Parties. Principles for Practice, The Hague 2012, s. 27. Zgodnie z $\$ 3$ powołującego Komisję rozporządzenia Prezydenta (Constitution Review Commission of Inquiry Instrument, 2010 z 11 stycznia 2010 r.) zakres działania Komisji obejmował: (a) ustalenie poglądów Ghańczyków dotyczących funkcjonowania Konstytucji, w szczególności jej mocnych i słabych stron; (b) wyartykułowanie obaw Ghańczyków związanych z całościową zmianą Konstytucji; (c) sformułowanie rekomendacji dla Rządu i przygotowanie projektu ustawy o zmianie Konstytucji. W swoim raporcie (s. 10) Komisja podkreśla, że jej mandat nie ograniczał się do oceny tekstu Konstytucji, ale obejmował także ocenę sposobu jej stosowania. 
końcow ${ }^{69}$, w którym zawarła projekty ustaw o zmianie licznych i zróżnicowanych pod względem wagi i tematyki postanowień Konstytucji, zarówno zwykłych, jak i zasadniczych, mające służyć jej „udoskonaleniu” i „unowocześnieniu”. W czerwcu 2012 r. do propozycji CRC oficjalnie, w formie Białej Księgi, odniósł się rząd, akceptując jednak tylko niewielką ich częśćc ${ }^{70}$; następnie Prezydent utworzył kolejną komisję (CRIC Constitution Review Implementation Committee), która miała zająć się przekształceniem zaaprobowanych przezeń propozycji CRC w projekty ustaw o zmianie Konstytucji. Proces zmiany Konstytucji uległ zawieszeniu, po tym jak w lipcu 2014 r. Stephen Kwaku Asare, profesor prawa z Uniwersytetu Florydzkiego, skierował do Sądu Najwyższego Ghany wniosek kwestionujący konstytucyjność utworzenia i działalności CRC, a także dalszych wynikających z tego działań innych podmiotów. W październiku 2015 r. Sąd Najwyższy sformułowane w skardze zarzuty uznał jednak za niezasadne (wielokrotnie cytowany wyrok z 14 października 2015 r. w sprawie Asare vs Attorney General). W 2016 r. powrócono do prac nad zmianą Konstytucji, podejmując nawet - na cztery miesiące przed wyborami parlamentarnymi i prezydenckimi - próbę uchwalenia niewielkiej części tych już wcześniej procedowanych, nie uzyskały one jednak wymaganej większości w Parlamencie. Proces przeglądu Konstytucji, choć ostatecznie nie doprowadził do żadnych zmian w jej tekście, rzeźbił zatem ghańską politykę i organizował debatę publiczną przez kilka kolejnych lat. Wydaje się zresztą, że w zamyśle inicjujących i kontynuujących go polityków właśnie to mogło być jego głównym celem.

Zasady zmiany Konstytucji nie stanowiły głównego tematu prac CRC, znalazły jednak znaczący wyraz w jej raporcie ${ }^{71}$. Zgodnie z zawartymi tam informacjami część uczestników zorganizowanych przez Komisję debat i konsultacji - będących jedną z podstawowych form jej działania, obejmujących zróżnicowane grupy społeczne - przekonywała, że Konstytucja z 1992 r. funkcjonuje zbyt krótko, aby ją zmie-

69 Raport został opatrzony podtytułem From a political to a developmental constitution i liczy aż 984 stron (dane bibliograficzne w przyp. 51).

70 Government of Ghana, White Paper on the Report of the Constitution Review Commission of Inquiry, Accra 2012.

71 Raport CRC, s. 746-751. 
niać $^{72}$, a ewentualne problemy wynikają z jej niestosowania (czy też niewystarczającego wcielania w życie - under-enforcement), nie zaś z samego sposobu sformułowania jej tekstu ${ }^{73}$. Zamiast zatem poddawać Konstytucję szerokiej zmianie - przekonywano - należy pozwolić jej na swobodny rozwój, przede wszystkim poprzez orzecznictwo Sądu Najwyższego. Nieraz dodawano przy tym, że największe wyzwania, przed jakimi stoi obecnie Ghana, są związane z kulturą rządzenia oraz poziomem życia materialnego, a więc sprawami, które w ograniczonym stopniu wynikają z samego tekstu Konstytucji. Część uczestników tych debat i konsultacji zwracała przy tym uwagę, że w ghańskim społeczeństwie (wciąż) można odnaleźć wiele postaw, które nie pozwalają na pełną realizację ideałów konstytucyjnych.

Zarazem przytłaczająca większość uczestników konsultacji, jak wskazuje Komisja w swoim raporcie, uznała, że istnieje potrzeba jakiejś zmiany Konstytucji. Nawet ci z nich, którzy twierdzili, że obowiązująca Konstytucja jest bardzo dobra, mieli przyznawać, że wymaga ona pewnych niewielkich i punktowych zmian ${ }^{74}$. Część uczestników konsultacji przekonywała także, że co jakiś czas należy, niejako dla zasady, podejmować próbę przeglądu Konstytucji. Argumentowano, że możliwość bezpośredniego i szerokiego udziału obywateli w debacie konstytucyjnej stanowi wartość samą w sobie, niezależnie od tego, czy ostatecznie doprowadzi ona do zmiany Konstytucji (zdaniem samej Komisji taka debata miałaby skutek wręcz katarktyczny). Część zwolenników tej koncepcji proponowała nawet stworzenie, w drodze zmiany Konstytu-

72 L. Bini, Przewodniczący Narodowej Komisji Edukacji Obywatelskiej, jeszcze na etapie powstawania CRC stwierdził wręcz, że Konstytucja nie jest gotowana na zmiany - należy pozwolić jej funkcjonować jeszcze przez co najmniej cztery, pięć pokoleń. O. Anny, GHANA: Constitution Under the Knife, 11 lutego 2010 r., globalissues. org/news/2010/02/11/4499 (dostęp 20 sierpnia 2017 r.).

73 Por. O. Anny, op. cit.; por. także African Peer Review Mechanism, Country Review Report of the Republic of Ghana, Midrand 2005, s. 121 i inne.

74 W tym kontekście można dodać, że nawet część spośród tych, którzy przekonywali, że utworzenie CRC nie jest właściwym, zwłaszcza z prawnego punktu widzenia, środkiem mającym prowadzić do zmian w Konstytucji, dostrzegała potrzebę tych zmian. Tak np. S.K. Asare (autor wspomnianego wniosku do SN), H.K. PrempeH, op. cit., s. 6-7 (którzy ogólnie sam tekst Konstytucji oceniają, jak się wydaje, pozytywnie). 
cji, mechanizmu jej cyklicznego przeglądu, argumentując, że zmiana Konstytucji jest zbyt poważnym przedsięwzięciem, aby uzależniać ją od „kaprysów i zachcianek” kolejnych rządów. Mechanizm cyklicznego przeglądu Konstytucji - który ostatecznie nie musiałby prowadzić do jej zmiany - pozwalałby ich zdaniem na uwzględnienie dynamicznej natury społeczeństwa, a rządowi na odpowiednio wczesne przygotowanie się do tego przedsięwzięcia ${ }^{75}$. Część uczestników konsultacji proponowała także utworzenie stałej komisji do spraw zmian w Konstytucji.

Sami autorzy raportu zręcznie balansują między różnymi opiniami dotyczącymi potrzeby i charakteru zmian, jakie ujawniły się w toku debat i konsultacji - chętnie komplementują Konstytucję, wychodząc z założenia, że to „dobry dokument”76, zarazem wskazują, że zarówno sam tekst Konstytucji, jak i praktyka jego stosowania w wielu obszarach wymagają zmian, dodają jednak, że należy wystrzegać się zmian pochopnych, w końcu zwracają uwagę, że Konstytucja to żywy organizm ${ }^{77}$. Niejako w odpowiedzi na propozycje stałego bądź cyklicznego jej przeglądu, Komisja zwraca uwagę, że w Ghanie działają już liczne instytucje powołane do oceny prawa - w szczególności Komisarz do spraw Oceny Prawa Stanowionego oraz Komisja Reform Prawnych, a także mająca status organu konstytucyjnego Narodowa Izba Wodzów - rekomendując jednak harmonizację ich działań, w końcu dodając nawet, że należałoby je upoważnić do cyklicznego przeglądu Konstytucji, na przykład co 10 lat ${ }^{78}$. Poza tą sugestią CRC nie przedstawiła jednak żadnych propozycji zmian w zakresie procedury zmiany Konstytucji.

75 Wśród dyskutantów nie było jednak zgodności co do częstotliwości takiego przeglądu - sugestie wahały się w przedziale od 5 do 20 lat. W raporcie CRC brak jest przy tym informacji, czy zwolennicy wprowadzenia tego mechanizmu postulowali wykluczenie możliwości zmiany Konstytucji w „zwykłym okresie”, między tymi przeglądami. Podobnie brakuje tam informacji o tym, czy zmiana Konstytucji będąca skutkiem owego cyklicznego przeglądu byłaby proceduralnie łatwiejsza.

76 Raport CRC, s. 30.

77 Raport CRC, s. 2, 30 i inne.

78 Raport CRC, s. 754-755. Mimo że ta propozycja ma charakter fundamentalny, Komisja w żaden sposób jej nie rozwija, co więcej, pomija ją w rekomendacjach podsumowujących problematykę trybu zmiany Konstytucji (które to rekomendacje nie 
Przedmiotem dyskusji i konsultacji organizowanych przez Komisję stały się również postanowienia amnestyjno-indemnizacyjne (art. 34, 35 i 37 Pierwszego Załącznika) - mimo że Konstytucja wyraźnie mówi o ich niezmienności. Problematyka ich ewentualnej zmiany została przy tym w raporcie Komisji omówiona stosunkowo szeroko ${ }^{79}$.

Komisja informuje, że autorzy przesłanych jej opinii nie zastanawiali się nad problemem prawnej dopuszczalności zmiany postanowień amnestyjno-indemnizacyjnych, wypowiadając się jedynie o samej ich treści ${ }^{80}$. Problem konstytucyjności ich zmiany pojawił się dopiero w czasie zorganizowanej w marcu 2011 r. Narodowej Konferencji Konstytucyjnej (National Constitution Review Conference) ${ }^{81}$, jednak jej uczestnicy nie osiągnęli w tej sprawie porozumienia. Podczas gdy jedni przekonywali, że zmiana tych postanowień jest prawnie niemożliwa, inni twierdzili, że ponieważ podmiotem suwerenności w Ghanie jest naród, za prawnie i wręcz moralnie naganne należy uznać sugestie, w myśl których Ghańczycy nie mogą zmienić któregoś z przepisów swojego najwyższego prawa. Niektórzy zwolennicy drugiego z tych poglądów zastrzegali jednak, że zmiana postanowień amnestyjno-indemnizacyjnych byłaby możliwa dopiero po zmianie art. 299 i rozdziału XXV Konstytucji (tzw. podwójna zmiana (rewizja) ${ }^{82}$ ).

dotyczą zresztą zasad jej zmiany, ale uproszczenia i zuniwersalizowania pod względem płci (gender neutral) jej języka, a także edukacji konstytucyjnej).

79 Raport CRC, s. 792-800.

80 Z tego też względu to właśnie zagadnienie celowości - a nie dopuszczalności - ich utrzymania, usunięcia lub modyfikacji stanowi gros rozważań stosownego podrozdziału raportu CRC.

81 Celem Konferencji, opatrzonej tytułem The Constitution: Our Identity, miało być „rozpoczęcie procesu budowy konsensusu wokół głównych zagadnień związanych ze zmianą Konstytucji” (Raport CRC, s. 14).

82 Dopuszczalność zmiany konstytucyjnej zasady określającej niezmienność innych zasad czy przepisów konstytucyjnych jest od dawna przedmiotem rozważań doktryny i orzecznictwa w innych systemach konstytucyjnych, prowadzących jednak do zróżnicowanych wniosków. Por. np. Tryb zmiany konstytucji w wybranych państwach członkowskich Unii Europejskiej, red. K. KubuJ, J. WaWrzyniaK, Warszawa 2010, s. 59 (Francja), s. 175 (Portugalia) czy s. 226 (Włochy). Z tym zagadnieniem nieraz ściśle wiąże się rozróżnienie na ustrojodawcę pierwotnego i wtórnego i zakres ich uprawnień, 
Tak czy inaczej ostatecznie Narodowa Konferencja Konstytucyjna opowiedziała się za utrzymaniem postanowień amnestyjno-indemnizacyjnych. Jej uczestnicy wskazywali, że usunięcie tych postanowień byłoby „prawnie kosztowne”, czasochłonne, mogłoby generować chaos, w końcu mogłoby także „podać w wątpliwość całą Konstytucję”; podnoszono także, że ponieważ „negocjacje nad porozumieniem na rzecz powrotu do rządów konstytucyjnych nie rządziły się przypadkiem”, usunięcie tych postanowień „miałoby poważne konsekwencje dla całego narodu oraz stabilności naszej młodej demokracji" ${ }^{\prime 3}$.

Sama CRC nie zajmuje w swoim raporcie wyraźnego stanowiska w sprawie prawnej dopuszczalności modyfikacji czy też uchylenia postanowień amnestyjno-indemnizacyjnych, koncentrując się na społeczno-politycznym kontekście tego problemu - i w tym zakresie stanowisko ma już dość jednoznaczne. Komisja zwraca uwagę, że klauzule te są "głęboko zakorzenione" w Konstytucji, w związku z czym skuteczność ich ewentualnej zmiany wymagałaby konsensusu, który, jak się wydaje, obecnie nie jest możliwy do osiągnięcia. W konsekwencji zadanie ich usunięcia określa jako „trudne, a być może niemożliwe”84. Komisja, jak czytamy w jej raporcie, podziela fundamentalną zasadę, zgodnie z którą rozwój każdego państwa i społeczeństwa powinien opierać się na równości wobec prawa i odrzuceniu bezkarności, zarazem uważa, że należy mieć na względzie potrzebę zachowania narodowej jedności oraz pokojowej koegzystencji. Równocześnie zachęca do pełniejszego wdrożenia rekomendacji Narodowej Komisji Pojednania ${ }^{85}$.

Również członkowie Parlamentu w swoim raporcie wskazującym 44 obszary wymagające refleksji konstytucyjnej opowiedzieli się za

ale także wątpliwość co do tego, kiedy mamy do czynienia $\mathrm{z}$,już nową” konstytucją, a kiedy tylko ze zmianami w tej dotychczasowej.

83 Raport CRC, s. 799-800.

84 Raport CRC, s. 797.

85 Raport CRC, s. 800. Do tej ostatniej sprawy rząd w swojej Białej Księdze się jednak nie ustosunkował. 
zachowaniem postanowień amnestyjno-indemnizacyjnych ${ }^{86}$. Do tego samego wniosku doszedł także rząd ${ }^{87}$.

\section{UWAGI KOŃCOWE}

Konstytucja Ghany z 1992 r. należy niewątpliwie do konstytucji sztywnych, zarówno w znaczeniu formalnym - związanym z prawnym ukształtowaniem zasad jej zmiany - jak i w sensie faktycznym ze względu na jak dotąd tylko jedną niewielką zmianę jej tekstu. O jej sztywności decydują przede wszystkim istotnie zaostrzone w stosunku do zwykłego trybu ustawodawczego - ale i bez takiego porównania bardzo wymagające - warunki jej zmiany, na czele z koniecznością uzyskania 2/3 głosów w Parlamencie lub 3/4 w ogólnokrajowym referendum (próg w innych konstytucjach niemal niespotykany ${ }^{88}$ ). Wymogi te ulegają niejako dodatkowemu zaostrzeniu ze względu na strukturę ghańskiej sceny politycznej, od powstania IV Republiki podzielonej na dwa przeciwstawne obozy, wymieniające się władzą w cyklach czterobądź ośmioletnich. O formalnej sztywności tej Konstytucji świadczy również wyraźne określenie w samym jej tekście materialnych granic jej zmiany, z nad wyraz precyzyjnym sformułowaniem niezmienności samej klauzuli niezmienności.

Sztywność zasad zmiany ghańskiej Konstytucji, w połączeniu z jej objętością i szczegółowością - należy ona do jednych z dłuższych współczesnych aktów konstytucyjnych ${ }^{89}$ - warunkuje zarazem sztywność całego ghańskiego systemu ustrojowego. Ponieważ zaś ustroje

86 Raport CRC, s. 800.

87 Raport CRC, s. 800; Government of Ghana, White Paper..., op. cit., s. 50.

88 Próg 3/4 głosów w referendum w sprawie zmiany konstytucji przewiduje np. art. 148 Konstytucji Litwy z 1992 r., odnosi się on jednak do zmiany art. 1 stanowiącego, że Litwa jest niepodległą republiką demokratyczną. W przypadku Ghany próg ten trzeba przekroczyć także w przypadku znacznie mniej istotnych zmian konstytucyjnych.

${ }^{89}$ Złożona z 336 artykułów i niedługich części „nieartykułowych” Konstytucja Ghany liczy ok. 55 tys. wyrazów. Dla porównania Konstytucja RP z 1997 r., której nieraz zarzuca się zbyt dużą objętość (paradoksalnie nieraz towarzyszy temu zarzut niejasności i ogólnikowości), liczy ok. 14 tys. wyrazów (obliczenia własne). Taka długość 
państwowe, a w jeszcze większym stopniu sami politycy, aby przetrwać i się umacniać, muszą, jak już powiedziano, pozostawać w ciągłym ruchu, szczególnego znaczenia nabiera trzeci - obok tekstu Konstytucji i ustaleń nauki prawa - wymiar jej funkcjonowania, czyli sposób jej stosowania, zarówno przez polityków - których tak daleko idąca sztywność tekstu Konstytucji może wręcz zachęcać do kształtowania (deformowania) systemu konstytucyjnego poprzez niekonstytucyjną praktykę polityczną - jak i przez sądy, które te polityczne pokusy mogą powstrzymywać; tu szczególną rolę może odgrywać Sąd Najwyższy, działając jako „ustawodawca” zarówno negatywny, jak i pozytywny.

I chociaż przykład ghański potwierdza, że sztywność zasad zmiany konstytucji może chronić jej tekst przed zmianami, które nie mają poparcia w szerokim konsensie społecznym, to zarazem pokazuje, że nawet tak wyrazista forma jej usztywnienia jak sformułowanie w samym jej tekście postanowień niezmienialnych nie musi stanowić przeszkody dla debaty nad dopuszczalnością i zasadnością ich zmiany - tej w końcu ustrojodawca nie zakazał - przynajmniej po upływie pewnego czasu; choć debata ta tej sztywności - w sensie społeczno-politycznej percepcji prawa - nie musi służyć. Przykład ghański nie jest tu zresztą jedynym - znane są przecież przypadki nie tylko naukowej dyskusji nad przynajmniej prima facie niezmienialnymi postanowieniami konstytucyjnymi, lecz także zupełnie niewysublimowane próby odchodzenia od podstawowych zasad demokratycznych, na przykład poprzez zmiany konstytucji w drodze ustaw zwykłych - jest jednak o tyle interesujący, że debata nad zmianą postanowień niezmienialnych dotyczy tych (indemnizacyjno-amnestyjnych), które znacząco przyczyniły się do wprowadzenia samej demokracji konstytucyjnej, a w kolejnych latach zapewniały jej przetrwanie, wraz z jej utrwalaniem się mając w tym jednak coraz mniejszy udział. W tym kontekście dodatkowego, nieco przewrotnego znaczenia nabiera popularne twierdzenie, że debata jest solą demokracji.

tekstu ghańskiej Konstytucji może jednak wynikać także z jej zakładanej zapewne przez ustrojodawcę funkcji edukacyjnej. 
Oceniając dopuszczalność i zasadność debaty nad zmianą formalnie niezmienialnych postanowień amnestyjno-indemnizacyjnych, warto wziąć pod uwagę możliwy (jeszcze pozostały) czas ich faktycznego obowiązy wania. Z naturalnych względów - to jest z uwagi na długość życia adresatów tych przepisów, zarówno przedstawicieli dawnych reżimów wojskowych, jak i osób przez nich poszkodowanych - przepisy te za jakiś czas staną się o ile nie martwymi, to zamierającymi. Pojawia się zatem pytanie, czy wraz z upływem tego czasu nie rozpłynie się również formalna zasada ich niezmienności, a w konsekwencji - czy dopuszczalne stałoby się ich usunięcie (choćby ze względów symbolicznych czy wręcz tylko redakcyjnych). Z jednej strony można by twierdzić, że dopóki możliwość ich zastosowania - choćby w odniesieniu do jednej tylko osoby - będzie istnieć, dopóty sens będzie miał argument zakładający, że zmiana tego, co niegdyś uznano za niepodlegające zmianie, stanowiąc wyłom w obowiązywaniu zakazów i nakazów konstytucyjnych, może godzić w społeczne zaufanie do Konstytucji jako takiej. Z drugiej strony wydaje się mało prawdopodobne, aby próba usunięcia przepisów, które w społecznym odczuciu są zamierające, jeśli nie już martwe, mogła prowadzić do tak dalekich konsekwencji. Istotną rolę w rozstrzyganiu tego rodzaju dylematów może mieć geneza tych przepisów - choć z pewnością ułatwiły one przejście do systemu demokratycznego, to jednak, jak powiedziano, do tekstu Konstytucji zostały wprowadzone w sposób niedemokratyczny; zarzutem niedemokratyczności bądź niewystarczającego demokratyzmu z powodzeniem można jednak objąć także pozostałe etapy przygotowywania i wprowadzania tej Konstytucji. Równocześnie należałoby wziąć pod uwagę, że już stosunkowo długi czas obowiązywania tej Konstytucji, ukształtowana na jej gruncie tradycja i kultura demokratyczna, w końcu także jej społeczna legitymizacja powodują, że obecnie tego rodzaju zarzuty w przestrzeni publicznej nie są silnie reprezentowane. 
Tryb I GRanice Zmiany Konstytucji Ghany Z 1992 R.

\section{Streszczenie}

Celem opracowania jest przybliżenie problematyki formalnych i materialnych ograniczeń zmiany obecnie obowiązującej, uchwalonej prawie 30 lat temu, Konstytucji Ghany, będących interesującym wyrazem transformacji z autorytaryzmu do demokracji. Ponieważ Ghana to państwo, które w zachodnich rankingach stanu demokracji, praworządności i przestrzegania praw człowieka od lat sytuuje się w ścisłej czołówce afrykańskiej - a w najnowszych osiąga wyniki bardzo podobne do Polski - warto tym bardziej przyjrzeć się jej bliżej. Na artykuł składają się: krótka charakterystyka historii ustroju Ghany, jej Konstytucji i systemu politycznego; szczegółowe omówienie zagadnienia wewnętrznej hierarchii postanowień konstytucyjnych oraz kolejnych etapów - w znacznej mierze oryginalnej - procedury ich zmiany; próba identyfikacji granic zmiany Konstytucji, w tym analiza będących wyrazem sprawiedliwości tranzytywnej niezmienialnych postanowień amnestyjno-indemnizacyjnych; przedstawienie i ocena toczącej się w ubiegłej dekadzie debaty nad zmianą Konstytucji, obejmującej również problematykę zasad i granic jej zmiany. Tekst kończą wnioski dotyczące sztywności tej Konstytucji, wynikającej z czynników zarówno prawnych, jak i pozaprawnych.

\section{Procedures and Limits to the Amendment of the 1992 Constitution of GHana}

\section{Summary}

The aim of this article is to outline the formal and material limitations to the amendment of the currently binding Constitution of Ghana, which was enacted almost 30 years ago. Ghana is an interesting example of transformation from authoritarianism to democracy. This article takes a closer look at Ghana, a country that Western rankings have for many years acknowledged as one of the African leaders for democracy, rule of law and protection of human rights. In the latest data Ghana is ranked with almost the same results as Poland. The article comprises a brief 
characteristic of Ghana's constitutional history and its constitutional and political system; a detailed analysis of its domestic hierarchy of constitutional provisions and the subsequent procedural stages of their amendment, many of them original; an attempt to identify the limits to Ghana's constitutional amendments, including an examination of the unamendable constitutional provisions on indemnity, which are an expression of transitional justice; and an outline and assessment of the debate on changing the Constitution conducted in the last decade including procedures and limits of constitutional amendment. The conclusions address the question of the rigidity of the Constitution of Ghana due both to legal and non-legal factors.

Słowa kluczowe: zmiana konstytucji; sztywność konstytucji; aksjologia demokracji; konstytucyjne postanowienia niezmienialne; sprawiedliwość tranzytywna; debata nad zmianą konstytucji.

Keywords: constitutional amendment; constitutional rigidity; the axiology of democracy; unamendable constitutional provisions; transitional justice; debate on constitutional amendment.

\section{Literatura}

Авака E., Ghana: Revolution and Fourth Republic, 1981 to Present, [w:] Encyclopedia of African History, t. 1: A-G, red. K. Shillington, New York-London 2005, s. 580-582.

African Peer Review Mechanism, Country Review Report of the Republic of Ghana, Midrand 2005.

Amnesty International, Ghana 2019, amnesty.org/en/countries/africa/ghana/ report-ghana (dostęp 1 czerwca 2020 r.).

Anny O., GHANA: Constitution Under the Knife, 11 lutego 2010 r., globalissues. org/news/2010/02/11/4499 (dostęp 20 sierpnia 2017 r.).

Asare S.K., To Review or not to Review the CRC Judgment, graphic.com.gh/images/ pdfs/Asare_opinion.pdf (dostęp 3 lutego 2017 r.).

Asare S.K., Prempen H.K., Amending the Constitution of Ghana: Is the Imperial President Trespassing?, "African Journal of International and Comparative Law»18.2/2010, s. 192-216.

Bertelsmann Stiftung, BTI 2020 Country Report - Ghana, Gütersloh 2020, bti-project.org/content/en/downloads/reports/country_report_2020_GHA. pdf (dostęp 1 czerwca 2020 r.). 
Boafo-Arthur K., A decade of liberalism in perspective, [w:] Ghana: One Decade of the Liberal State, red. K. Boafo-Arthur, New York 2007, s. 1-20.

European Commission, Action Document for the Ghana Anti-Corruption, Rule of Law and Accountability Programme (Ghana-ARAP) (ANNEX 1 of the Commission Decision on the Annual Action Programme 2015 in favour of the Republic of Ghana), b.m.w. 2015.

Gyimah-Boadi E., Brobbey V., Countries at the Crossroads 2012: Ghana, b.m.w. 2012, freedomhouse.org/sites/default/files/Ghana\%20-\%20FINAL.pdf (dostęp 1 czerwca 2020 r.).

Folson K.G., Ideology, Revolution and Development - the Years of J.J. Rawlings, [w:] Ghana Under PNDC Rule, red. E. Gyimah-BoAd, Dakar 1993, s. 74-95.

Freedom House, Countries and Territories, freedomhouse.org/countries/freedom-world/scores oraz Freedom in the World 2021: Ghana, freedomhouse.org/ country/ghana/freedom-world/2021 (dostęp 4 sierpnia 2021 r.).

Friedrich Ebert-Stiftung Ghana, The Law-making Process in Ghana: Structures and Procedures, Accra 2011, library.fes.de/pdf-files/bueros/ghana/10506. pdf (dostęp 9 czerwca 2020 r.).

GARLICKi L., Normy konstytucyjne relatywnie niezmienialne, [w:] Charakter i struktura norm konstytucji, red. J. Trzciński, Warszawa 1997, s. 137-155.

Ghana 1992, princeton.edu/ pcwcr/reports/ghana1992.html (dostęp 15 marca 2017 r.).

Government of Ghana, White Paper on the Report of the Constitution Review Commission of Inquiry, Accra 2012.

Gyampo R., Dealing with Ghana's winner-takes-all politics: The case for an independent Parliament, «Governance Newsletter» 20.1/2015, s. 1-13.

How laws are made, parliament.gh/laws, dostęp 9 czerwca $2020 \mathrm{r}$.

imani Center for Policy \& Education, IMANI Policy Debate Series: Does Ghana Have A Winner-Takes-All Constitution?, imaniafrica.org/2014/09/14/ imani-policy-debate-series-does-ghana-have-a-winner-takes-all-constitution-2 (dostęp 14 września 2017 r.).

Institute of Economic Affairs, Democracy Consolidation Strategy Paper. An Issues Paper, Accra 2008.

Tryb zmiany konstytucji w wybranych państwach członkowskich Unii Europejskiej, red. K. KubUJ, J. WAWrZYNiaK, Warszawa 2010.

McCaskie T.C., [Ghana] Recent History, [w:] Africa South of the Sahara 2004, red. K. Murison, London-New York 2004, s. 475-479.

Piotrowski R., Konstytucja i granice władzy suwerena w państwie demokratycznym, [w:] Dwadzieścia lat obowiązywania Konstytucji RP. Polska myśl 
konstytucyjna a międzynarodowe standardy demokratyczne, red. J. JASKIERNIA, K. SPRYSZAK, Kielce 2017, s. 702-727.

Piotrowski R., Zagadnienie granic zmiany konstytucji w państwie demokratycznym, [w:] Ustroje, doktryny, instytucje polityczne. Księga jubileuszowa Prof. zw. dra hab. Mariana Grzybowskiego, red. J. CzajKowsкi, Kraków 2007, s. 275-284. Piotrowski R., wypowiedź na wspólnym posiedzeniu Komisji Praw Człowieka, Praworządności i Petycji, Komisji Ustawodawczej oraz Komisji Samorządu Terytorialnego i Administracji Państwowej Senatu RP 4 maja 2020 r. poświęconym rozpatrzeniu ustawy z 6 kwietnia 2020 r. o szczególnych zasadach przeprowadzania wyborów powszechnych na Prezydenta Rzeczypospolitej Polskiej zarządzonych w 2020 r., stenogram dostępny na stronie senat.gov.pl/ prace/komisje-senackie/przebieg,8625,2.html.

Prempen H.K., Presidential Power in Comparative Perspective: The Puzzling Persistence of Imperial Presidency in Post-Authoritarian Africa, «Hastings Constitutional Law Quarterly» 35.4/2008, s. 761-834.

Report of the Constitution Review Commission, Accra 2011, constitutionnet.org/ sites/default/files/crc_research_report_final.pdf (dostęp 9 czerwca 2020 r.).

Reporters Without Borders, 2020 World Press Freedom Index, rsf.org/en/ ranking (dostęp 1 czerwca 2020 r.).

Roznai Y., Unconstitutional Constitutional Amendments - The Migration and Success of a Constitutional Idea, "The American Journal of Comparative Law» 61.3/2013, s. 657-719.

SARnecki P., Wstęp, [w:] Podstawowe ustawy ustrojowe Zjednoczonego Królestwa Wielkiej Brytanii i Irlandii Pótnocnej, Warszawa 2010, s. 1-43.

ShabAN A.R.A., Landslide approvals in Ghana referendum for new regions, 29 grudnia 2018 r., africanews.com/2018/12/29/landslide-approvals-in-ghana-referendum-for-new-regions (dostęp 4 sierpnia 2021 r.).

Shillington K., Ghana and the Rawlings Factor, London 1992.

The World Factbook - Ghana, cia.gov/the-world-factbook/countries/ghana/\#people-and-society (dostęp 4 sierpnia $2021 \mathrm{r}$.).

United States Agency for International Development, Ghana Democracy and Governance Assessment. Final Report, b.m.w. 2011.

United States Department of State - Bureau of Democracy, Human Rights and Labor, Country Reports on Human Rights Practices for 2016, Washington 2017.

van Vliet M., Wahiu W., Magolowondo A., Constitutional Reform Processes and Political Parties. Principles for Practice, The Hague 2012.

Yeebo Z., Ghana: The Struggle for Popular Power, London 1991. 